University of Tennessee Health Science Center

UTHSC Digital Commons

$12-2011$

\title{
Testing Whether MRP4 (a cAMP Efflux Pump) and the Beta 2 Andrenergic Receptor (an Upstream Regulator of cAMP Signaling Pathways
}

Praveen Kumar Potukuchi

University of Tennessee Health Science Center

Follow this and additional works at: https://dc.uthsc.edu/dissertations

Part of the Medical Molecular Biology Commons

\section{Recommended Citation}

Potukuchi, Praveen Kumar, "Testing Whether MRP4 (a cAMP Efflux Pump) and the Beta 2 Andrenergic Receptor (an Upstream Regulator of cAMP Signaling Pathways" (2011). Theses and Dissertations (ETD). Paper 212. http://dx.doi.org/10.21007/etd.cghs.2011.0252.

This Thesis is brought to you for free and open access by the College of Graduate Health Sciences at UTHSC Digital Commons. It has been accepted for inclusion in Theses and Dissertations (ETD) by an authorized administrator of UTHSC Digital Commons. For more information, please contact jwelch30@uthsc.edu. 


\title{
Testing Whether MRP4 (a cAMP Efflux Pump) and the Beta 2 Andrenergic Receptor (an Upstream Regulator of cAMP Signaling Pathways
}

\begin{abstract}
Background and Aim: MRP4/ABCC4 is an ABC transporter that can efflux the second-messenger, cAMP, from cells. MRP4 has a PDZ interacting motif at its carboxy terminal end through which it binds to scaffolding proteins NHERF1 and PDZK1. Previous studies have shown that PDZK1 serves as a scaffold physically coupling MRP4 with the cystic fibrosis transmembrane conductance regulator (CFTR). This protein complex functionally couples cAMP regulation of CFTR function with MRP4 CAMP transporter activity [Li, C., et al., Spatiotemporal coupling of cAMP transporter to CFTR chloride channel function in the gut epithelia. Cell, 2007. 131(5): p. 940-51]. We hypothesized that the MRP4 PDZ domain can bind MRP4 to scaffolding proteins other than NHERF1 and PDZK1 and that those PDZ proteins serve to physically and functionally link MRP4 to other proteins involved in CAMP signaling. High expression of MRP4 has been observed in normal prostate and in human prostate cancer cell lines such as LNCaP cells [Cai, C., et al., Androgen induces expression of the multidrug resistance protein gene MRP4 in prostate cancer cells. Prostate Cancer Prostatic Dis, 2007. 10(1): p. 39-45]. In these cells, there are reports that the !2 adrenergic receptor (!2AR), a G protein-coupled receptor that ultimately signals through cAMP, is also highly expressed [Kasbohm, E.A., et al., Androgen receptor activation by G(s) signaling in prostate cancer cells. J Biol Chem, 2005. 280(12): p. 11583-9]. !2AR also has a PDZ interacting motif at its carboxy terminal end. We hypothesized that in these cells there is the possibility of interaction between MRP4 and !2AR through a shared PDZ protein, leading to physical and functional association of these proteins.

Methodology: We probed Panomics PDZ protein arrays with biotinylated MRP4 peptides consisting of MRP4 PDZ interacting motif, and identified potential PDZ partner proteins to which MRP4 peptide binds. We used LNCaP cells to quantify the mRNA expression of these putative PDZ partner proteins, as well as MRP4 and !2AR. We carried out pull down assays to test for physical association between the three proteins. We used a cAMP reporter assay to test whether activation of !2AR induced cAMP signaling and determine whether this signaling was modulated by MRP4 expression.
\end{abstract}

Results: Out of 93 PDZ domains, MRP4 showed interaction with 24 PDZ domains. The five candidate PDZ proteins chosen for further studies met the following criteria: (a) They were documented in the literature to interact functionally with GPCRs (G protein-coupled receptors) that upon stimulation couple with G" proteins and cause a rise in intracellular cAMP, and (b) They were expressed in prostate cells and colocalized with MRP4. Based on previous studies, only two PDZ domains, NHERF1 and MAGI3, were reported to bind with G"s, which is a subunit responsible for production of cAMP in response to activation of certain type of GPCRs. LNCaP cells have higher expression of MRP4 and !2AR (a G protein-coupled receptor that binds G"s subunit). Using pull down assays, we showed a physical association between MRP4 and !2AR. We also showed a functional association between !2AR and MRP4, because inhibition of MRP4 modulated !2AR-induced cAMP signaling in LNCaP cells.

Conclusion: MRP4 is physically and functionally associated with the !2AR in LNCaP cells. This association may be facilitated by a scaffolding protein, which may be MAGI3. This protein may be responsible for holding the macromolecular complex of two proteins, MRP4 and !2AR. This association may be important for regulating cAMP levels in LNCaP cells and affecting the downstream expression of certain genes that depend on the cAMP signal transduction.

\section{Document Type}

Thesis 


\section{Degree Name}

Master of Science (MS)

\section{Program}

Biomedical Sciences

Research Advisor

Erin G. Schuetz, PhD

\section{Keywords}

ABCC4, Beta 2 Adrenergic Receptor, PDZ Proteins

\section{Subject Categories}

Medical Molecular Biology | Medical Sciences | Medicine and Health Sciences 
Testing Whether MRP4 (a cAMP Efflux Pump) and the Beta 2 Andrenergic Receptor (an Upstream Regulator of cAMP Signaling Pathways) Are Physically and Functionally Coupled by PDZ Proteins

\author{
A Thesis \\ Presented for \\ The Graduate Studies Council \\ The University of Tennessee \\ Health Science Center
}

\author{
In Partial Fulfillment \\ Of the Requirements for the Degree \\ Master of Science \\ From The University of Tennessee
}

By

Praveen Kumar Potukuchi

December 2011 
Copyright (C) 2011 by Praveen Kumar Potukuchi All rights reserved. 


\section{To Shiridi Sai Baba}

and

To my parents, siblings, in-laws and my wife for their endless love and support. 


\section{ACKNOWLEDGEMENTS}

Completion of the daunting task of obtaining my Master of Science degree was only possible because of continuous help, support and guidance of many people. First and foremost I would like to express my deepest gratitude and heartfelt appreciation to my mentor, Dr. Erin Schuetz, for providing me an opportunity to work in her lab and also for instilling in me qualities for being a good researcher. Her cooperation and continued support have been major driving forces throughout my graduate career at St. Jude Children's Research Hospital and at the University of Tennessee. I would like to thank my committee members, Dr. Bernd Meibohm and Dr. Alexander Sparreboom, for their invaluable suggestions, guidance and assistance.

I was fortunate to get guidance from MRP4 guru Dr. John Schuetz and want to thank him for his suggestions and help. I would like to thank and also am indebted to Dr. Patrick Ryan for all his support and help from the start to the completion of my graduate studies journey at the University of Tennessee Health Science Center. I am grateful to the Department of Pharmaceutical Sciences and St. Jude Children's Research Hospital for their support, help and guidance in this journey.

A special thanks to my colleagues Ranjit, Amarjit, Jeremey, Satish, Mugdha, Deepa, Steve and Sarah for their help and encouragement in providing me hands-on experience with different techniques. I would also like to thank Vinay, Subbarao, Pavan, Kishore and Vamshi for their support, company and confidence in me. I extend gratitude to all my friends for their friendship and encouragement.

I would like to thank my parents, siblings, in-laws and my wife; no words are enough to thank them for their support and patience during the completion of this thesis. I would also like to thank all my teachers from kindergarten through graduate school for igniting in me the light of knowledge. Finally, I would like to thank the Almighty for everything that I have today. 


\begin{abstract}
Background and Aim: MRP4/ABCC4 is an ABC transporter that can efflux the second-messenger, cAMP, from cells. MRP4 has a PDZ-interacting motif at its carboxy terminal end through which it binds to scaffolding proteins NHERF1 and PDZK1.

Previous studies have shown that PDZK1 serves as a scaffold physically coupling MRP4 with the cystic fibrosis transmembrane conductance regulator (CFTR). This protein complex functionally couples cAMP regulation of CFTR function with MRP4 cAMP transporter activity [Li, C., et al., Spatiotemporal coupling of cAMP transporter to CFTR chloride channel function in the gut epithelia. Cell, 2007. 131(5): p. 940-51]. We hypothesized that the MRP4 PDZ domain can bind MRP4 to scaffolding proteins other than NHERF1 and PDZK1 and that those PDZ proteins serve to physically and functionally link MRP4 to other proteins involved in cAMP signaling. High expression of MRP4 has been observed in normal prostate and in human prostate cancer cell lines such as LNCaP cells [Cai, C., et al., Androgen induces expression of the multidrug resistance protein gene MRP4 in prostate cancer cells. Prostate Cancer Prostatic Dis, 2007. 10(1): p. 39-45]. In these cells, there are reports that the $\beta 2$ adrenergic receptor ( $\beta 2 A R)$, a $G$ protein-coupled receptor that ultimately signals through cAMP, is also highly expressed [Kasbohm, E.A., et al., Androgen receptor activation by $G(s)$ signaling in prostate cancer cells. J Biol Chem, 2005. 280(12): p. 11583-9]. $\beta 2 A R$ also has a PDZ-interacting motif at its carboxy terminal end. We hypothesized that in these cells there is the possibility of interaction between MRP4 and $\beta 2 \mathrm{AR}$ through a shared PDZ protein, leading to physical and functional association of these proteins.
\end{abstract}

Methodology: We probed Panomics PDZ protein arrays with biotinylated MRP4 peptides consisting of MRP4 PDZ interacting motif, and identified potential PDZ partner proteins to which MRP4 peptide binds. We used LNCaP cells to quantify the mRNA expression of these putative PDZ partner proteins, as well as MRP4 and $\beta 2 \mathrm{AR}$. We carried out pull down assays to test for physical association between the three proteins. We used a cAMP reporter assay to test whether activation of $\beta 2 A R$ induced cAMP signaling and determine whether this signaling was modulated by MRP4 inhibition.

Results: Out of 93 PDZ domains, MRP4 showed interaction with 24 PDZ domains. The five candidate PDZ proteins chosen for further studies met the following criteria: (a) They were documented in the literature to interact functionally with GPCRs ( $\mathrm{G}$ protein-coupled receptors) that upon stimulation couple with $\mathrm{G} \alpha$ proteins and cause a rise in intracellular cAMP, and (b) They were expressed in prostate cells and co-localized with MRP4. Based on previous studies, only two PDZ domains, NHERF1 and MAGI3, were reported to bind with Gas, which is a subunit responsible for production of cAMP in response to activation of certain types of GPCRs. LNCaP cells have higher expression of MRP4 and $\beta 2 A R$ (a $G$ protein-coupled receptor that binds Gas subunit). Using pull down assays, we showed a physical association between MRP4 and $\beta 2 \mathrm{AR}$. We also showed a functional association between $\beta 2 \mathrm{AR}$ and MRP4, because inhibition of MRP4 modulated $\beta 2$ AR-induced cAMP signaling in LNCaP cells. 
Conclusion: MRP4 is physically and functionally associated with the $\beta 2 \mathrm{AR}$ in LNCaP cells. This association may be facilitated by a scaffolding protein, which may be MAGI3. This protein may be responsible for holding the macromolecular complex of two proteins, MRP4 and $\beta 2 \mathrm{AR}$. This association may be important for regulating cAMP levels in LNCaP cells and affecting the downstream expression of certain genes that depend on the cAMP signal transduction. 


\section{TABLE OF CONTENTS}

CHAPTER 1. INTRODUCTION .....................................................................................

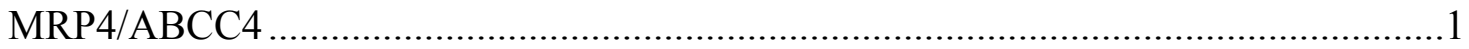

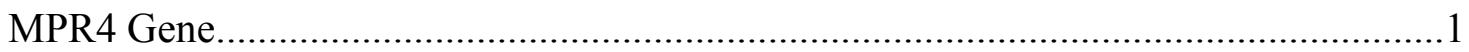

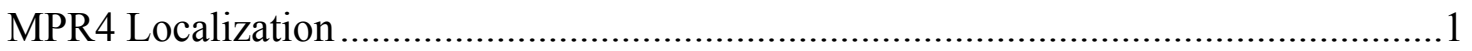

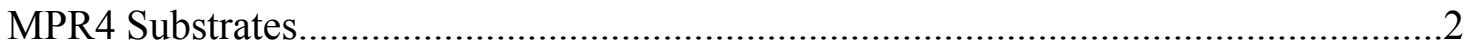

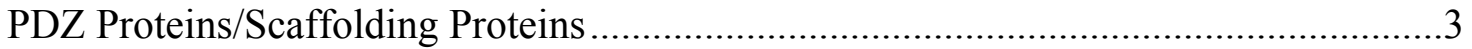

Scaffolding Proteins Classification......................................................................... 3

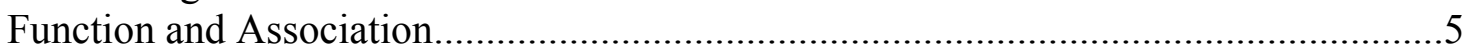

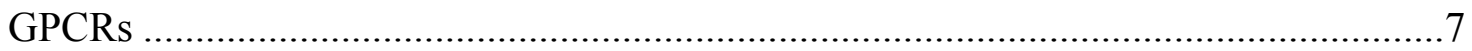

Classification of GPCRs ............................................................................. 7

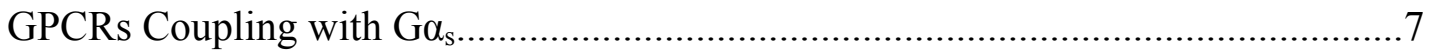

CHAPTER 2. MATERIALS AND METHODS.........................................................10

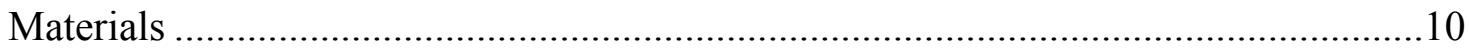

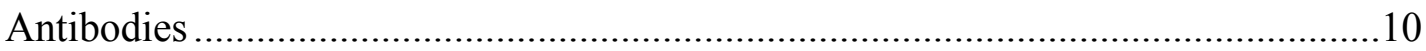

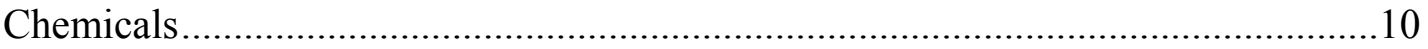

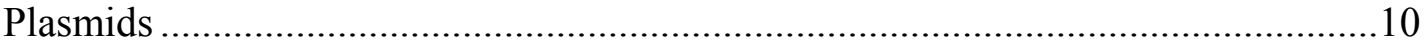

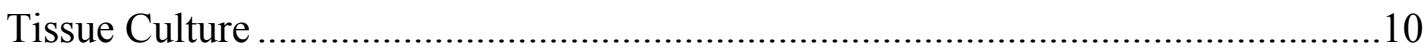

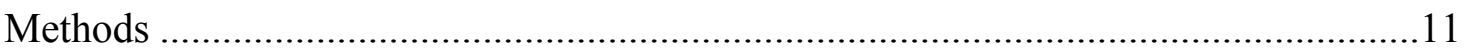

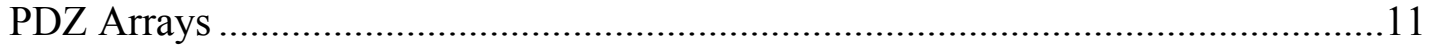

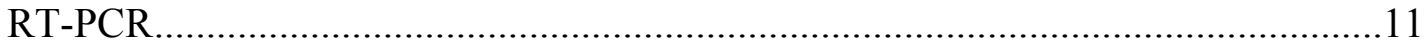

CRE (cAMP Response Element) Luciferase Reporter Assay ..................................11

Pull-down Assay, Co-immunoprecipitation and Immunoblotting ............................12

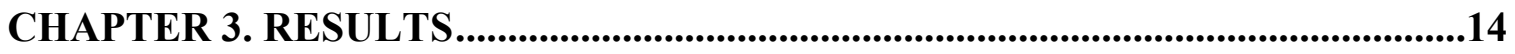

ABCC4/MRP4 PDZ Domain Interactions or MRP4 PDZ Interactome ........................14

MRP4, $\beta 2 \mathrm{AR}$ and MAGI3 are Co-Expressed in LNCaP Cells ...................................27

ABCC4/MRP4 Interacts with $\beta 2 \mathrm{AR}$ in LNCaP Cells ............................................27

Inhibition of MRP4 along with $\beta 2 \mathrm{AR}$ Activation Modifies cAMP Signaling ..............30

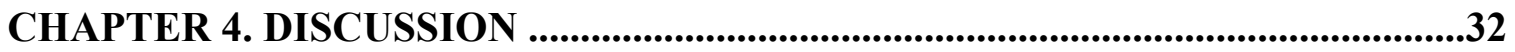

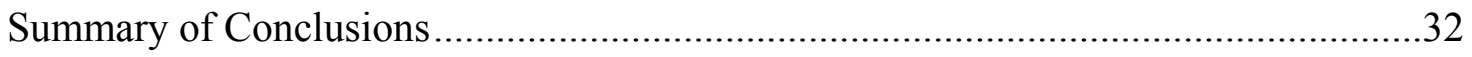

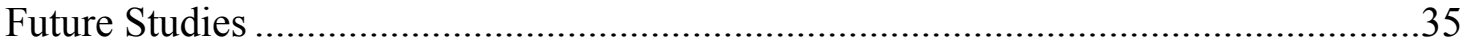

LIST OF REFERENCES...........................................................................................36

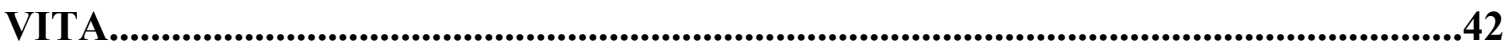




\section{LIST OF TABLES}

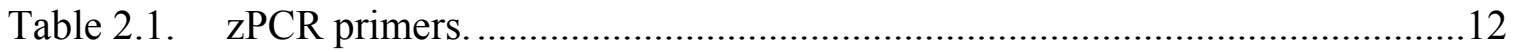

Table 3.1. PDZ domains on arrays II, III and IV which bound with MRP4 C7

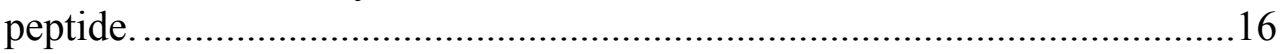

Table 3.2. Potential PDZ proteins that interact with GPCRS which bound to MRP4

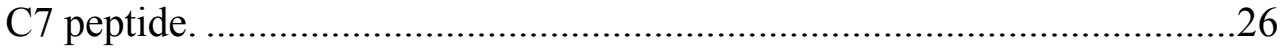




\section{LIST OF FIGURES}

Figure 3.1. Interaction of the MRP4 Class I PDZ domain with PDZ domains of various scaffolding proteins..............................................................15

Figure 3.2. MRP4, $32 \mathrm{AR}$ and MAGI3 expression in $\mathrm{LNCaP}$ cells.............................28

Figure 3.3. MRP4 interacts with B2AR through scaffolding protein MAGI3. ..............29

Figure 3.4. Activation of $\beta 2 A R$ along with inhibition of MRP4 modifies cAMP

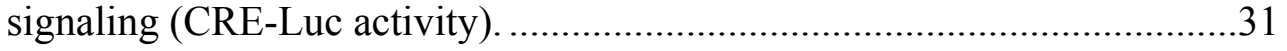

Figure 4.1. Schematic representation of physical and functional association of MRP4 with B2AR through a scaffolding protein, MAGI3, in prostate

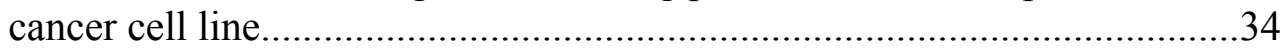




\section{LIST OF ABBREVIATIONS}

$\beta 2 \mathrm{AR}$

ABCC4

ATP

AZT

CAL

cAMP

CFTR

cGMP

CNrasGEF

ERK

ISO

MAGI3

MRP4

MUPP1

NHERF 1

OAT4

OCTN $1 / 2$

PDGFR

PEPT1/2

PGE

PMEA

URAT1
Beta 2 Adrenergic Receptor

ATP-binding Cassette Sub-family C Member 4

Adenosine Triphosphate

Azidothymidine

CFTR Associated Ligand

Cyclic Adenosine Monophosphate

Cystic Fibrosis Transmembrane Conductance Regulator

Cyclic Guanosine Monophosphate

Cyclic Nucleotide Ras Guanine Nucleotide Exchange Factor

Extracellular Signal-Regulated Kinases

Isoproterenol

Membrane-associated Guanylate Kinase Inverted 3

Multidrug Resistance Protein 4

Multi-PDZ Domain Protein 1

$\mathrm{Na}+/ \mathrm{H}+$ Exchanger Regulatory Factor 1

Organic Anion Transporter 4

Carnitine/Organic Cation Transporter

Platelet-Derived Growth Factor Receptor

Peptide Transporter

Prostaglandin E

9-(2-phosphonyl Methoxyethyl)

Urate Transporter 1 


\section{CHAPTER 1. INTRODUCTION}

\section{MRP4/ABCC4}

Drug transporters play an essential role in absorption, distribution and excretion of drugs. Drug transporters are broadly classified as uptake and efflux transporters. Uptake transporters are those that transport drugs into cells, and efflux transporters are those that efflux drugs out of cells. Multi drug resistance protein 4 or MRP4/ABCC4 is an efflux transporter that belongs to $\mathrm{C}$ subfamily of $\mathrm{ABC}$ transporters.

Though MRP4 was discovered as a homologue of MRP1 [3] in 1997, its valuable function as an efflux transporter of antiviral drugs [4] was discovered a couple of years later. Subsequent research on this transporter also revealed that MRP4 substrates are endogenous compounds, such as cAMP [5]. Some of the ABCC transporters (e.g., MRP2, CFTR and MRP4) have a unique feature of having a PDZ domain at their carboxy terminal end-a domain that aids in protein-protein interactions. This PDZ domain allows the transporter to bind to PDZ proteins. The PDZ proteins can bind multiple proteins with PDZ domains, and thus they function as a scaffold to facilitate physical interactions between these $\mathrm{ABC}$ transporters with other transporters, receptors and ion channels, leading to involvement in and subsequently effecting different signaling pathways. Before exploring the wide range of MRP4 substrates, let us look at the gene structure, protein expression patterns and localization of MRP4 along with different domains that are present in the protein.

\section{MPR4 Gene}

MRP4 gene is a highly polymorphic gene [6] that consists of 31 exons and 30 introns. There are multiple MRP4 alternative mRNAs. Alternative splicing of alternative exons 1a and exon $1 \mathrm{~b}$ singly and in combination can occur. In some transcripts the presence of these alternative exons leads to formation of premature termination codons and the mRNA transcripts undergoes nonsense mediated decay. This mechanism may act as a regulator for expression of transcripts of MRP4 in a particular cellular environment, which subsequently may control the expression of functional MRP4 protein [7]. While MRP4 is ubiquitously expressed, localization of MRP4 is unique when compared to more restricted cellular/tissue localization of MRP2 or CFTR [8, 9]. In addition, while MRP2 and CFTR are apically expressed, MRP4 in some tissues is apically localized and in other tissues is basally localized [5].

\section{MPR4 Localization}

MRP4 is basolaterally localized in tissues like prostate, liver and brain choroid plexus. Higher expression of MRP4 has been observed in prostate [10] and it is localized at the basolateral membrane of tubuloacinar cells[5]. The expression pattern of MRP4 is 
observed to be different between normal and prostate cancer cells. In prostate cancer cell lines and also in prostate cancer patient samples, higher expression of MRP4 has been reported $[1,11]$. But gene expression analysis of prostate cancer tissues taken from benign and malignant tumors has shown an opposite trend-lower expression of MRP4 mRNA in malignant tumors [12]. This difference in expression pattern of MRP4 in patient samples and cell lines has not yet been noticed or addressed. In liver, MRP4 is localized on the basolateral membrane (sinusoidal side). Loss of MRP4 (MRP4 knockdown mice) in obstructive cholestatsis leads to tissue damage, which may not be compensated by the change in expression of other transporters to protect liver from the cholestatic injury. This shows that induced MRP4 expression in cholestatsis protects liver from excessive bile acid accumulation [13].

Dual localization of MRP4 has been observed in brain and human colonic epithelial cells. In brain choroid plexus epithelium, MRP4 is localized to the basolateral membrane of choroid plexus epithelium, and apically localized in brain capillary endothelial cells. This dual localization of MRP4 aids in protection of brain. However, in CNS disease conditions, the dual localization may prevent the entry of drugs into the brain. This entry issue may be bypassed by using specific MRP4 inhibitors [14]. Dual localization is also observed in colonic epithelial cells, but in these cells higher expression of MRP4 is observed at the apical side of the cells [15]. In kidney proximal tubules, MRP4 is expressed on the apical membrane of the cells, and this localization helps in efflux of substrates of MRP4 into urine[16].

\section{MPR4 Substrates}

Large numbers of substrates are effluxes by MRP4 and can be broadly classified as drugs or endogenous compounds. Some of these substances can act as MRP4 inhibitors. Drugs that are effluxed by MRP4 include antiviral drugs like AZT, PMEA, Adefovir and Tenofovir and also anticancer drugs like Methotrexate and Topotecan. MRP4 inhibitors include MK571, probenecid, sildenafil and dipyridamole. There are a large number of endogenous compounds that are also substrates of MRP4, including cAMP, cGMP, bile acids, PGE1 and PGE2 [5]. Many observations show that MRP4 is one of the major regulators of intracellular cAMP levels. cAMP is a second messenger that is mainly produced by the activation of $\mathrm{G}$ Protein coupled receptors. This activation of GPCRs receptors stimulates adenyl cyclase, ultimately leading to cAMP production.

As mentioned above, cAMP is a second messenger, is involved in several signaling pathways. It has been observed that cAMP is involved in cell growth, differentiation and gene expression[17]. cAMP can activate apoptosis or cell growth, and that decision can depend on the cell type $[18,19]$. It is important to control cellular cAMP levels. Low or high cAMP levels lead to different diseases or cytotoxicity[15]. Elevated levels of cAMP have been observed in prostate carcinogenesis[20]. Intracellular cAMP levels are generally regulated by two mechanisms-hydrolysis by phosphodiesterases[21] and ATP-dependent efflux [22]. 
In human colonic cancer epithelial cells, it has been observed that MRP4 controls the localized cAMP levels, compartmentalizing cAMP into "cAMP microdomains" [1]. In the same cells, it has also been observed that MRP4 interacts with CFTR. This interaction is possible because of the physical binding of both CFTR and MRP4 to a scaffolding protein, PDZK1. Both CFTR and MRP4 bind to PDZK1 through their PDZ interaction domain [15]. MRP4 protein consists of two membrane spanning domains and two nucleotide binding domains. These domains are a signature of $\mathrm{ABC}$ transporters. MRP4 C terminal consists of a PDZ interacting motif or a protein-protein interaction domain. Through this domain, MRP4 can bind to PDZ domain proteins called scaffolding proteins. As mentioned above, this binding with scaffolding proteins aids MRP4 in interacting with other proteins that also bind to scaffolding proteins through their PDZ interacting motif.

\section{PDZ Proteins/Scaffolding Proteins}

Cells maintain homeostasis of signaling, which is the process of relaying the message or stimuli they receive from extracellular molecules to intracellular molecules and subsequently affecting the downstream targets of these signaling through proteinprotein interactions. Protein-protein interactions play a central role in maintaining the balance in various signaling pathways. In mammalian cells, there are a large number of protein molecules involved in cellular signaling [22]. Though we know that through protein-protein interactions cells maintain signaling homeostasis, it is surprising that cells control these interactions by having the right proteins interact at the right time and at the right place without forming wrong networks in the communications [23]. Cells achieve this spatio-temporal regulation of proteins by arranging them in complexes and by anchoring some of them to the plasma membrane and arranging others in sub-cellular locations [24].

In organizing these protein-protein interactions, some proteins acts as bridges and connect with other proteins by bringing them together into a complex. These proteins are called adapter proteins or scaffolding proteins. Adapter proteins are the proteins that aid in forming the complex between two other proteins. If there are more than two proteins in the complex, then the bridging protein is called the scaffolding protein. Both adapters and scaffolding proteins may anchor the interacting proteins to the membrane [25].

\section{Scaffolding Proteins Classification}

Scaffolding proteins consist of many protein-protein interaction domains; quite commonly they have multiple PDZ domains. Initially these domains were observed as sequence repeats in proteins in which they are present and were named GLGF domains. The acronym PDZ was coined based on the first letter present in each protein, i.e., $\mathrm{P}$ (from PSD 95/SAP 90, Post Synaptic Density 95), D from (DLG, Disc Large Protein) and Z from (ZO1, Zonula Occludens) [26]. PDZ domains can be classified into two 
types - simple/complex scaffolding proteins and family based proteins. Simple scaffolding proteins are those proteins that only have PDZ domains, e.g., PDZK1 and PDZK2. Complex scaffolding proteins are those proteins that have other protein interaction domains along with PDZ domains, e.g., NHERF1, MAGI3 and MUPP1, etc. [27]. Family-based proteins are classified based on a family. For example, family of PDZ proteins with only PDZ domains, MAGUK family proteins, or proteins additionally having other protein domains along with PDZ domains [24, 28].

Scaffolding proteins are classified based on families, and one such family is MAGUK. Proteins in this family have approximately six PDZ domains and these proteins may play a role in tumor suppression and cell surface expression of interacting proteins. MAGUK family has been classified into subfamilies, one subfamilies being MAGI-Membrane-associated guanylate kinase inverted orientation. MAGI3 belongs to the MAGI family. MAGI 1 and 2 are scaffolding proteins, each having a specific expression pattern. MAGI 1 and 3 are widely expressed. MAGI1 is highly expressed in brain and MAGI2 also has neuronal expression [29]. MAGI3 is a tight junction protein with six PDZ domains, two WW domains and one GUK domain [30]. Localization of MAGI3 has been observed both in nucleus and tight junctions in different cellular environments [31]. MAGI3 PDZ domain has shown binding with TGF $\alpha$ [32], Frizzle, Ltap [33]], receptor tyrosine kinase [34] and $\beta 1$ AR [31]. PDZ domain 3 MAGI3 binds PTEN [35]. PDZ domain 5 interacts with LPA2 and BAI-1 [[30]. NMDA receptor binds to PDZ domain 6 of MAGI3 [31].

PDZ domains are 80-90 amino acid length sequences and can bind to the carboxy terminal of PDZ domain interacting motifs of interacting proteins or to the internal motifs of interacting proteins. PDZ domains can homodimerize with other PDZ domains in the same protein or heterodimerize with PDZ domains of other PDZ proteins and can also interact with lipids [36]. Interaction or binding of the PDZ domain with carboxy terminal PDZ domain interacting motifs may be a simple tethering when they are in proximity or through an allosteric regulation [37]. PDZ domain interacting motifs are broadly classified into four classes (with some exceptions). This classification is based on the interaction of their last three amino acids $(0,-1$ and -2$)$ with PDZ domains [38, 39].

Class I PDZ motifs are the ones that have a pattern of "X-T/S-X- $\Phi / \Psi$ " where $\mathrm{X}$ is any amino acid at -3 position, $T / S$ ( $T$ is threonine, $S$ is serine) at -2 position, $X$ is any amino acid at -1 position and $\Phi / \Psi$ ( $\Phi$ is hydrophobic, $\Psi$ is aromatic) at position 0 mostly. In class I PDZ motis, at 0 position there would be $\mathrm{V} / \mathrm{L}$ ( $\mathrm{V}$ is valine, $\mathrm{L}$ is leucine). Some of the transporters either in SLC or ABC come under the class I PDZ motifs. Proteins with class I PDZ motifs include MRP2, CFTR, MRP4, OAT4, OCTN1, OCTN2 and B2AR $[26,27,38]$. Class II PDZ motifs have the following pattern of amino acids at their carboxy terminal "X- $\Phi / \Psi-\mathrm{X}-\Phi / \Psi$," which is any amino acid at -3 position, hydrophobic or aromatic amino acid at -2 position, any amino acid at -1 position and hydrophobic/ aromatic amino acid 0 position. Proteins having class II PDZ domains are Neurexin, Syndecan and dopamine transporter (DAT) [26, 38, 40]. Class III PDZ motifs have the pattern of "G/E-D/E-X- $\Phi / \Psi$ " amino acids at their carboxy terminal end. Class III motifs have $\mathrm{G} / \mathrm{E}$ ( $\mathrm{G}$ is glycine, $\mathrm{E}$ is glutamic acid) amino acid at their -3 position, $\mathrm{D} / \mathrm{E}$ 
at -2 position ( $\mathrm{D}$ is aspartic acid, $\mathrm{E}$ is glutamic acid), any amino acid at -1 position and a hydrophobic/aromatic amino acid at 0 position. Proteins having class III PDZ motifs are melatonin receptor, KIF17, myotilin and FATZ.[26, 38]. Class IV proteins have the pattern of "X-X- $\Psi-\mathrm{D} / \mathrm{E} / \#$," which is any amino acid at -3 and -2 positions, aromatic amino acid at -1 position and $\mathrm{D} / \mathrm{E} / \#$ at 0 position (\# any amino acid other than $\Phi / \Psi$ ). Computationally, class IV motif has been observed in some ion channels and viral proteins, but in vivo analysis does not yet confirm the in vitro or computational findings $[38,39]$.

\section{Function and Association}

Interaction of proteins having PDZ domain interacting motifs with proteins having PDZ domains results in the formation of a protein-protein complex, as mentioned above. This complex formation may result in physical and/or functional interaction of proteins. This interaction may even aid in cell surface expression of the interacting proteins and may also affect different signal transduction pathways in which these interacting proteins are involved [27]. Our interest is in interactions between transporters and their interacting partners, like ion channels, receptors and other transporters, etc. These interactions may affect the drug metabolism or disposition, or it may affect the transport of endogenous compounds, subsequently affecting signal transduction associated with it.

Functional association of PDZK1, a scaffolding protein, has been observed with transporters like OCTN1, OCTN2, URAT1, PEPT1 and PEPT2. A profound effect of the association of PDZK1 was observed upon its interaction with OCTN2. When PDZK1 is cotransfected with OCTN2, a 6-fold increase in carnitine transport by OCTN2 has been observed. An increase in transport was also observed with OCTN1, URAT1 and PEPT1 when these respective transporters are cotransfected with PDZK1 [38, 41-45].

Physical association of scaffolding proteins with transporters may bring different transporters or receptors near to each other, leading to indirect physical association and direct functional association of interacting transporters or transporters with receptors. PEPT1/ PEPT2 and NHE3 transporters and scaffolding proteins PDZK1 and NHERF1 are co-expressed primarily on the apical membrane of cells [46, 47]. Uptake of substrates by both PEPT1/PEPT2 depends on an $\mathrm{H}^{+}$gradient as NHE3 is expressed on the same membrane and has been proven as the supplier of $\mathrm{H}^{+}$gradient $[48,49]$. As the scaffolding proteins are expressed on the same membrane of the cells and can interact with the above-mentioned transporters, the functional association of NHE3 with PEPT1/PEPT2 may be aided by the physical association of transporters to different domains of same scaffolding proteins PDZK1 or NHERF1. It may be also possible that these transporters may bind to either of the scaffolding proteins and these scaffolding proteins may heterodimerize and bring the transporters into the vicinity of each other [27, 48].

Along with functional and physical association of proteins with PDZ motifs, PDZ domain proteins regulate or aid cell surface expression of interacting proteins [27]. 
Membrane proteins are anchored to the membrane and internalized into cells for degradation or recycled back to the cell surface. Transporters having PDZ motifs are mostly anchored to the apical membranes in polarized cells. PDZ motifs may play a role in the sorting of transporters to the membrane along with other signals that are required for membrane anchoring [27, 50,51]. Membrane sorting of transporters like MRP2, CFTR and MRP4 in some cell types is based on the interaction between the PDZ motif and PDZ domains of scaffolding proteins [27, 47, 51, 52]. Along with sorting, scaffolding proteins also regulate the stability of the interacting proteins/transporters; this stabilization leads to an increase in the transport activity of the transporters, which has been observed when transporters and scaffolding proteins are cotransfected. An opposite effect was observed with mutation of the PDZ motifs/ PDZ domains or transfecting transporters alone [42, 49, 53, 54]. One way of increasing stability would be controlling or reducing internalization of membrane proteins. CFTR interacts with NHERF1 and as NHERF1 interacts with actin through its ERM domain, this interaction may reduce the internalization of CFTR by preventing endocytosis [55].

Thus scaffolding proteins also control the stability and cell surface expression of interacting proteins/transporters by regulating internalization or recycling of interacting proteins [56, 57]. CFTR recycling frequency was decreased when its PDZ motif was deleted, leading to a decrease in its half-life at the membrane [57]. Knock down of NHERF1 resulted in a change in the frequency of recycling of MRP2, leading to a decrease of MRP2 protein at the membrane [58]. On the other hand, when interaction between NHERF1 and MRP4 is disrupted, a decrease in internalization of MRP4 with increasing amounts of MRP4 at the membrane has been observed. This may be due to a decrease in recycling [59]. Internalization and recycling regulates signal transduction along with cell surface expression and stability when the interactions involved are either receptors/transporters with scaffolding proteins. Beta2 adrenergic receptor recycling is affected by the breaking of its binding with NHERF1 [60].

Signal transduction pathways are also regulated by the interaction of scaffolding proteins with proteins having PDZ motifs This may be due to the effect of these interactions on functional and physical association or cell surface expression, or on stability as mentioned above. CFTR and MRP4 are physically and functionally associated through PDZK1, and this association of the two transporters leads to compartmentalized regulation of signal transduction of cAMP required for the function of CFTR [36]. Also, $\beta 2 \mathrm{AR}$ and CFTR are physically and functionally associated through NHERF1, and this association allows compartmentalized regulation of CFTR channel function through the $\beta 2$ receptor. As $\beta 2 \mathrm{AR}$ regulates cAMP levels, and cAMP is essential for regulating CFTR mediated chloride secretion, the macromolecular complex between the receptor and the transporter maintains homeostasis of signal transduction mediated by the receptor and the the transporter [61].

MRP4 is an efflux transporter of cAMP, and G protein coupled receptors are one of the upstream regulators of cAMP. Both the MRP4 transporter and GPCRs have class I PDZ motifs at their carboxy terminal ends. GPCRs are involved in numerous signaling 
pathways, and their function is also regulated by scaffolding proteins because these receptors interact with scaffolding proteins through their PDZ motif.

\section{GPCRs}

G Protein coupled receptors belong to the family of seven transmembrane spanning proteins. GPCRs are membrane-bound receptors whose localization and internalization and signaling are mediated through protein-protein interactions. GPCRs' activation by an agonist leads to activation of heterotrimeric $\mathrm{G}$ protein subunits $\alpha, \beta$ and $\gamma$. In other words, activation of GPCRs leads to dissociation of the complex of $\alpha, \beta$ and $\gamma$ into $\mathrm{G}_{\alpha}$ and $\mathrm{G}_{\beta \gamma}$ subunits. These subunits can activate or inhibit the downstream substrates or effectors. $G_{\alpha}$ subunit can be classified or referred to as four different subunits: $G \alpha_{\text {s }}$ activates adenylyl cyclase, $\mathrm{G} \alpha_{\mathrm{i}}$ inhibits adenylyl cyclase and activates $\mathrm{GIRK}, \mathrm{G} \alpha_{12 / 13}$ activates Rho GEFs and $\mathrm{G} \alpha_{\mathrm{q}}$ activates phospholipase [62-64].

\section{Classification of GPCRs}

Beta adrenergic receptors mostly couple with $\mathrm{G} \alpha_{\mathrm{s}}$ and activate adenylyl cyclase. These receptors belong to the family of GPCRs. There are three subtypes of beta adrenergic receptors: Beta 1 is highly expressed in heart and brain, beta 2 is ubiquitously expressed and beta 3 is expressed in adipose tissue. Beta 2 and 3 adrenergic receptors are also capable of coupling $\mathrm{G} \alpha_{\mathrm{i}}$ in certain cell types or tissues. All three receptors share a homology of approximately $50 \%$. When these receptors couple with $\mathrm{G} \alpha_{\mathrm{s}}$ after stimulation with an agonist, $\mathrm{G} \alpha_{\mathrm{s}}$ activates adenylyl cyclase, leading to generation of cAMP. This generated cAMP activates PKA $[36,65]$-following which, GPCRs $\beta_{1}$ and $\beta 2$ AR couple with $\mathrm{G} \alpha_{\mathrm{s}}$

Although there is high sequence similarity between beta 1 and 2 adrenergic receptors, each receptor has a unique expression pattern. In certain cell types both receptors are co-expressed. However, after activation by agonists, which leads to increase in similar cAMP levels, they have different effects on the downstream effectors. Both receptors have class I PDZ domain at their carboxy terminal end, but they bind to different scaffolding proteins. One of the reasons for this behavior may be due to the difference in expression patterns of scaffolding proteins [31, 65].

\section{GPCRs Coupling with $\mathbf{G} \boldsymbol{\alpha}_{\mathrm{s}}$}

$\beta 1 \mathrm{AR}$, through its PDZ interacting motif, binds to different scaffolding proteins which effect the receptors' localization and signal transduction. Interaction of $\beta 1 \mathrm{AR}$ with CAL prevents it from recycling to the plasma membrane, and interaction of MAGI2 with $\beta 1 \mathrm{AR}$ promotes receptor internalization. But the interaction of $\beta 1 \mathrm{AR}$ with PSD-95 inhibits receptor internalization [66-68]. As mentioned above, interaction of $\beta 1 \mathrm{AR}$ with scaffolding proteins affects the signal transduction pathways. $\beta 1 \mathrm{AR}$ binds with its PDZ 
interacting motif to the scaffolding protein CNrasGEF. When $\beta 1 \mathrm{AR}$ is activated by an agonist like isoproterenol, it leads to the dissociation of $\mathrm{G} \alpha_{\mathrm{s}}$ from the heterotrimeric complex, thus activating adenylyl cyclase and subsequently increasing cAMP levels in the cells. This cAMP binds to the catalytic domain of CNrasGEF, leading to the activation of Ras. This interaction of $\beta 1 \mathrm{AR}$ shows a direct relation between its signal transduction pathways and scaffolding protein interaction [69].

$\beta 1$ AR interaction with scaffolding proteins like GIPC and MAGI3 decreases ERK1/2 activation which is mediated through $\mathrm{G} \alpha_{\mathrm{i} .}$. It has been reported that coexpression of $\beta 1 \mathrm{AR}$ and MAGI3 led to greater membrane localization of MAGI3, and this localization may enhance the interaction between $\beta 1 \mathrm{AR}$ and other membrane proteins. Both GIPC and MAGI3 have no effect on the amount of cAMP generated and internalization of $\beta 1 \mathrm{AR}$, showing that some of the interactions with scaffolding proteins affect a part of signal transduction pathways instead of affecting the whole signal transduction pathways. $\beta 1 \mathrm{AR}$ and MAGI3 interaction was observed in various tissues like heart, brain and kidney [31, 70]

As mentioned earlier, $\beta 2 \mathrm{AR}$ also has class I PDZ domain similar to $\beta 1 \mathrm{AR}$, but each of these receptors interact with different PDZ proteins. The "DSLL" domain of $\beta 2 \mathrm{AR}$ is not conserved among other adrenergic receptors, and this may be one of the reasons for specific interactions of subtypes of adrenergic receptors, along with differential expression of scaffolding proteins $[31,65]$. $\beta 2 \mathrm{AR}$ couples with both $\mathrm{G} \alpha_{\mathrm{s}}$ and $\mathrm{G} \alpha_{i}$ proteins [71]. Agonist-stimulated $\beta 2 \mathrm{AR}$ interacts with NHERF1 and regulates NHE activity or, in other words, association of $\beta 2 \mathrm{AR}$ and NHERF1 activates NHE activity when $\beta 2 \mathrm{AR}$ is activated. But mutation in the PDZ motif of $\beta 2 \mathrm{AR}$ leads to the inhibition of NHE3 activity; this shows that association of $\beta 2 \mathrm{AR}$ with NHERF1 is required for regulation of NHE3 [65, 72-74]. $\beta 2 \mathrm{AR}$ sorting back to the membrane is also associated with its binding with NHERF1 [60]. $\beta 2$ AR and NHERF1 association also regulates PDGFR ERK signaling. This regulation is possible because both $\beta 2 A R$ and PDGFR can bind to NHERF1 through PDZ interacting motifs [65, 75].

$\beta 2 \mathrm{AR}$ associates with $\mathrm{P} 2 \mathrm{Y} 1$ receptor through its interaction with NHERF2 [76]. $\beta 2 A R$ peptide interacts with NHERF 1 and 2 and PDZK1 scaffolding proteins that were overlaid on a protein array. $\beta 1 \mathrm{AR}$ peptide was also used to probe these scaffolding proteins but the peptide interaction was with completely different scaffolding proteins. When the last amino acid of $\beta 1 \mathrm{AR}$, Valine, was changed to Leucine (or "ESKV" to "ESKL"), then the interactions were observed with NHERF 1 and 2 and PDZK1, an interaction which is similar to that of the $\beta 2 \mathrm{AR}$ peptide [31]. Both $\beta 2 \mathrm{AR}$ and $\beta 1 \mathrm{AR}$ bind to a scaffolding protein MAGI3, but they bind to different PDZ domains of the scaffolding protein. $\beta 2 \mathrm{AR}$ binds to $5^{\text {th }} \mathrm{PDZ}$ domain of MAGI 3 and $\beta 1 \mathrm{AR}$ binds to $1^{\text {st }}$. PDZ domain of MAGI3. One more difference is the following: Binding of $\beta 2 A R$ and MAGI3 is agonist stimulated, but $\beta 1 \mathrm{AR}$ and MAGI3 binding is constitutive. ERK 1/2 signaling is decreased when either of the receptors binds to MAGI3 [31, 77].

In this study, we observed that a MRP4 peptide containing its PDZ-interacting motif bound to several scaffolding proteins, included previously published interactions 
with NHERF1 and PDZK1. We report an interaction between MRP4, a cAMP efflux transporter, and $\beta 2 \mathrm{AR}$, an upstream regulator of cAMP signaling, which is likely happening through a novel scaffolding protein, MAGI3. 


\section{CHAPTER 2. MATERIALS AND METHODS}

To find the expression and also interaction, if any, between MRP4, $\beta 2 \mathrm{AR}$ and MAGI3 we used LNCaP cells. Below the different materials and methods that were used and applied to identify the expression and interaction between the three proteins are discussed.

\section{Materials}

\section{Antibodies}

MRP4 rat monoclonal antibody $\left(\mathrm{M}_{4} \mathrm{I}-10\right)$ its use has been described in the literature [14]. Sheep polyclonal antibody was raised against MAGI3 (PA1-12324, Pierce Antibodies, Rockford, IL, USA). Goat polyclonal antibody was raised against $\beta 2 \mathrm{AR}$ and Rabbit polyclonal antibody was raised against $\beta 2$ AR (ab40834 and ab36956, respectively, Abcam, Cambridge, MA, USA). Mouse monoclonal antibody was raised against NHERF1 (ALX-804-438, Enzo Life Sciences, Farmingdale, NY, USA).

\section{Chemicals}

Isoproterenol Hydrochloride (I6504, Sigma-Aldrich, St. Louis, MO) and MK571 (70720, Cayman Chemical, Ann Arbor, MI) are the chemicals that are used as $\beta 2 \mathrm{AR}$ and MRP4 agonist and inhibitor, respectively.

\section{Plasmids}

pCRE-MetLuc2, pMet-Luc2-Control and pSEAP2-Control plasmids (631745, 631717, Clonetech, Mountain View, CA) are the secreted luciferase transfected in LNCaP cells . PDZ arrays II-IV (Panomics TranSignal ${ }^{\mathrm{TM}}$, Panomics, Fremont, CA) are the arrays which were probed with MRP4 peptide. This MRP4 peptides are biotin conjugated containing the carboxy-terminal 7 a.a and 10 a.a (MRP4 C-7, C-10) of MRP4. These peptides were synthesized by the Hartwell Center at St. Jude Children's Research Hospital. Transfection reagent used was Fugene HD (04709705001, Roche, Mannheim,Germany)

\section{Tissue Culture}

LNCaP (human prostate adenocarcinoma) cells were obtained from ATCC and were cultured in RPMI 1640 supplemented with 10\% fetal bovine serum, 1\% penicillin/streptomycin, $1 \%$ glutamine and $1 \%$ sodium pyruvate. MDCK II cells stably 
over expressing empty vector or mMAGI3 were kindly provided by Dr. Robert J. Coffey (Vanderbilt University Medical Center). LLC-PK1 cells were grown in MEM 199 supplemented with $10 \%$ fetal bovine serum and $1 \%$ penicillin/streptomycin. Jurkat cells were grown in RPMI 1640 supplemented with 10\% fetal bovine serum, $1 \%$ penicillin/streptomycin and 1\% glutamine. Saos 2 cells stably expressing hMRP4 or empty vector were kindly provided by Dr. John Schuetz and were maintained in DMEM with $10 \%$ fetal bovine serum, $1 \%$ penicillin/streptomycin and $1 \%$ glutamine.

\section{Methods}

\section{PDZ Arrays}

Arrays consist of GST coupled to PDZ domains of scaffolding proteins (Panomics TranSignal $^{\mathrm{TM}}$. PDZ Domain Arrays II-IV). These arrays or membranes were incubated in $1 \mathrm{x}$ wash buffer for $30 \mathrm{~min}$. Then the membranes were incubated for 2 hours at room temperature in $5 \mathrm{ml}$ of $1 \mathrm{x}$ blocking buffer. $15 \mu 1$ of the biotin-MRP4 $\mathrm{C} 7 / \mathrm{C} 10$ peptide $(200 \mu \mathrm{M})$ was mixed with $15 \mu \mathrm{l}$ of avidin horsedish peroxidase $(1 \mathrm{mg} / \mathrm{ml})$ and incubated for $30 \mathrm{~min}$ at $4{ }^{\circ} \mathrm{C}$. The peptide avidin mix was added into $5 \mathrm{ml}$ of $1 \mathrm{x}$ blocking buffer (final MRP4 C7/C10 peptide concentration $600 \mathrm{nM}$ ) and incubated with the array for $2 \mathrm{hr}$ at room temperature. After incubation, membranes were washed three times in $1 \mathrm{x}$ wash buffer and binding of the peptide was detected using enhanced chemiluminescence and quantified using Bio-Rad universal hood II.

\section{RT-PCR}

Total RNA was isolated using TRIzol from LNCaP cells. First-strand cDNA was prepared using oligo (dT) primers (ThermoScript RT-PCR system, Invitrogen, Catalog number 11146-016). Real-time PCR quantitation of MRP4, $\beta 2 A R$, MAGI3 and GAPDH was carried out using the SYBR GreenER qPCR supermix (Invitrogen Catalog number 11760-100) according to the manufacturer's instructions. cDNA was analyzed in duplicate by quantitative real-time PCR on an ABI PRISM 7900HT Sequence Detection System (PE Applied Biosystems, Foster City, CA). Primers used for real-time quantification are provided in Table 2.1. The absolute $\mathrm{Ct}$ values of MRP4, $\beta 2 \mathrm{AR}$ and MAGI3 were normalized with absolute $\mathrm{Ct}$ values of GAPDH to obtain mRNA expression levels.

\section{CRE (cAMP Response Element) Luciferase Reporter Assay}

LNCaP cells grown in RPMI 1640 supplemented with 10\% charcoal stripped fetal bovine serum, $1 \%$ penicillin/streptomycin, $1 \%$ glutamine, $1 \%$ sodium pyruvate, were plated at $2 \times 10^{5}$ in a 24 well plate. After 24 hours, these cells are transfected with either 
Table 2.1. $\quad$ zPCR primers.

\begin{tabular}{lll}
\hline Gene & Forward Primer & Reverse Primer \\
\hline & & \\
MRP4 & CAACTCCTCTCCAAGGTGCT & ATCTGCTCACGCGTGTTCTT \\
B2AR & TCCTGGATCACATGCACAAT & GAGCACAAAGCCCTCAAGAC \\
MAGI3 & CACTTGCTGCAGTTTGTGGT & GAGCCCATCCGTCTCAAG \\
\hline
\end{tabular}

$1 \mu \mathrm{g}$ pCRE-MetLuc2 or the pMet-Luc2-Control vector and contransfected with $1 \mu \mathrm{g}$ pSEAP2-Control (secreted alkaline phosphatase) plasmid to control for transfection efficiency. After 24 hours of transfection, the media was changed with fresh medium containing $0.1 \%$ DMSO, Isoproterenol $(250 / 500 \mathrm{nM})$, MK571 $(25 \mu \mathrm{M})$ and Isoproterenol + MK571 $(250 / 500 \mathrm{nM}, 25 \mu \mathrm{M})$. These plasmids secrete luciferase protein in the media.

After 24 hours of treatment with the above-mentioned chemicals, media was collected and substrate was added according to the manufacturer's protocol. For normalization purposes, media was taken and SEAP substrate was added according to the manufacturer's protocol. Both luciferase and SEAP values were read on a luminometer, BioTek Synergy H4 hybrid reader, and the luciferase activities are normalized to SEAP values.

\section{Pull-down Assay, Co-immunoprecipitation and Immunoblotting}

LNCaP cells were plated at $1.5 \times 10^{6}$ in $10 \mathrm{~cm}$ dishes. After 24 hours of plating, media was removed and cells were washed twice with PBS and were scrapped using a scrapper in a solution of PBS + protease inhibitors. Cell lysates were collected in an eppendorf tube and centrifuged at $1,000 \mathrm{~g}$ for $5 \mathrm{~min}$ at $4 \mathrm{C}$. Then the supernatant was removed. To the remaining pellet, M-PER + Protease inhibitors (lysis buffer) were added and incubated on ice for $30 \mathrm{~min}$. Then the mixture is centrifuged at 14,000 $\mathrm{g}$ for $25 \mathrm{~min}$ at $4{ }^{\circ} \mathrm{C}$. Then the supernatant was taken and protein concentration of the cell lysates was determined by Bradford assay (Pierce, Rockford, IL). In case of isoproterenol treated cells, LNCaP Cells were plated at $1.5 \times 10^{6}$ in $10 \mathrm{~cm}$ dish. After $24 \mathrm{hr}$ of plating, isoproterenol $750 \mathrm{nM}$ was added to the cells and cells were lysed. Lysates $(500 \mu \mathrm{g})$ of $\mathrm{LNCaP}$ cells treated or untreated with isoproterenol was placed in tubes and the volume adjusted to $200 \mu \mathrm{l}$ using $\mathrm{Ab}$ binding and wash buffer provided by manufacturer. To this mixture, $\beta 2 \mathrm{AR}$ antibody (1:100), MRP4 antibody (1:50) and non-immune IgG were added, respectively (1:100 or 1:50), and this mixture was incubated for $20 \mathrm{hr}$ at $4{ }^{\circ} \mathrm{C}$ with constant mixing. After $20 \mathrm{hr}$, the mixture was incubated with Protein G Dynabeads for 4 hr at $4{ }^{\circ} \mathrm{C}$ with constant mixing. Then, 3 washes were done using wash buffer provided by Invitrogen, and mild elution was done using elution buffer provided by Invitrogen, and then denaturing elution was done using a mixture of M-PER + protease inhibitors with laemmli buffer (containing 5\% B-Mercaptoethanol). After adding the mixture, the denaturing elution was done by heating at $65^{\circ} \mathrm{C}$ for $10 \mathrm{~min}$. Elutes were separated on 7.5$10 \%$ SDS PAGE. For co-immunoprecpitation and immunoblotting, after separation on 
PAGE, the gel was transferred to PVDF membranes and immunoblotted using either anti-MRP4 or anti-32AR antibodies (immunoprecipitation or pull down). For co-immunoprecipitation, if the pull downwas done by anti-MRP4 antibody, then membranes were probed with anti- $\beta 2 A R$ and anti-MAGI3 antibodies. After pull down using anti- $\beta 2 A R$, antibody membranes were probed with anti-MRP4 and anti-MAGI3 antibodies.

For immunoblotting of MRP4, $32 \mathrm{AR}$ and MAGI3 in LNCaP, Saos2 cells expressing hMRP4 and MDCKII cells expressing mMAGI3 were plated at $1.5 \times 10^{6}$ in 10 $\mathrm{cm}$ dish. After $24 \mathrm{hr}$ of plating, media was removed and cells were washed twice with PBS and were scrapped using a scrapper in a solution of PBS + protease inhibitors. Cell lysates were collected (in case of Jurkat cells, because of being suspension cells, they were collected in eppendorf tube and centrifuged in an eppendorf tubes at $1,000 \mathrm{~g}$ for 5 min at $4{ }^{\circ} \mathrm{C}$. Then supernatant was removed and to the remaining pellet, M-PER+ Protease inhibitors (lysis buffer) were added and incubated on ice for $30 \mathrm{~min}$. Then the mixture was centrifuged at $14,000 \mathrm{~g}$ for $25 \mathrm{~min}$ at $4{ }^{\circ} \mathrm{C}$. Then supernatantwas taken and protein concentration of the cell lysates was determined by Bradford assay (Pierce, Rockford, IL). Elutes were separated on 7.5-10\% SDS PAGE and immunoblotting was performed after separation on PAGE. Gel was transferred to PVDF membranes and membranes were probed using anti-MRP4, anti- $\beta 2 \mathrm{AR}$ and anti-MAGI3 antibodies. 


\section{CHAPTER 3. RESULTS}

\section{ABCC4/MRP4 PDZ Domain Interactions or MRP4 PDZ Interactome}

MRP4/ABCC4, at its carboxy terminal, has a PDZ domain interacting motif. This is a class I motif "TAL" at its $-2,-1,0$ positions. Through this motif, MRP4 interacts with PDZ domains of PDZ proteins or scaffolding proteins. It has been observed that MRP4 through its PDZ domain interacting motif interacts with two scaffolding proteins, PDZK1 and NHERF1 $[36,78]$.We hypothesized that there may be other scaffolding proteins with which MRP4 may interact through its PDZ domain interacting motif. To investigate this hypothesis, we used two biotinylated MRP4 peptides (C7 and C10) to probe the Panomics protein arrays (II-IV). These arrays have 95 scaffolding proteins. Peptides C7 and $\mathrm{C} 10$ comprise the last seven and ten amino acids of the Carboxy-terminus of the MRP4 protein, respectively, with a linker and biotin at its N-terminus. C10 peptide has "STL" at its $-7,-8,-9$ position and resembles Class I PDZ domain interacting motif or an internal motif that can interact with PDZ domains of PDZ proteins. We used $\mathrm{C} 7$ peptide, which lacks "STL" amino acids that are present in the C10 peptide. This would give us an idea whether having "STL" or not makes any difference in binding or interaction with PDZ domain proteins. There were a number of interactions seen between the MRP4 C7 peptide and the PDZ proteins (Fig 3.1). Out of the 95 PDZ domains on the arrays (II-IV), the MRP4 C7 peptide interacted with 24 PDZ domains (Fig 3.1, Table 3.1). PDZK1 and NHERF1 PDZ domains were among the 24 domains that interacted with the MRP4 C7 peptide. This interaction supports the previously reported interaction of MRP4 protein with these PDZ proteins and also suggests that these interactions are not non-specific. PDZ domain arrays (II-III) were probed with MRP4 C10 peptide. Interactions that were observed were similar to MRP4 C7 peptide interactions, but there were three PDZ domains that have not interacted with MRP4 C10 peptide (data not shown). Results obtained from MRP4 C7 interaction are presented in Fig 3.1 and Table 3.1.

Because MRP4 is an efflux transporter of cAMP [36], and because receptors belonging to family of GPCRS are regulators of cAMP signaling pathways, [63, 79] we were interested in pursuing scaffolding proteins that bound with the MRP4 PDZ peptide and that further met two criteria:Tthey had to bind with GPCRs involved in cAMP signaling, and their expression and localization pattern had to be similar to that of MRP4 protein expression and localization. As mentioned earlier, these scaffolding proteins aid in protein-protein interactions and help different proteins to form a macromolecular complex, leading to synchronous operation of signaling pathways. From the $24 \mathrm{PDZ}$ domains that interacted with the MRP4 PDZ peptide, we identified 5 that are involved in binding with GPCRS, and that co-localized with MRP4 (Table 3.2).

We were interested in testing whether the in vitro MRP4 PDZ interactions observed by peptide and array probing could be observed between the full length MRP4 and scaffolding proteins and which are potential GPCR interacting proteins. We purposefully elected not to test for these interactions by transfecting cells with expression 
A MRP4 $C 7$ wt peptide: biotin-KSGSG-TIFETAL $\mathrm{COOH}_{\mathrm{C}}$ Linker MRP4

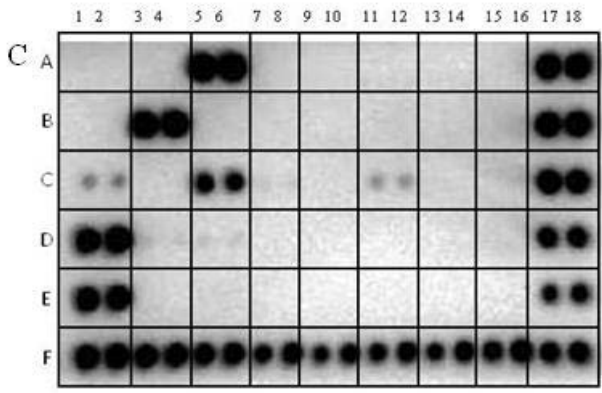

$\mathrm{E}$

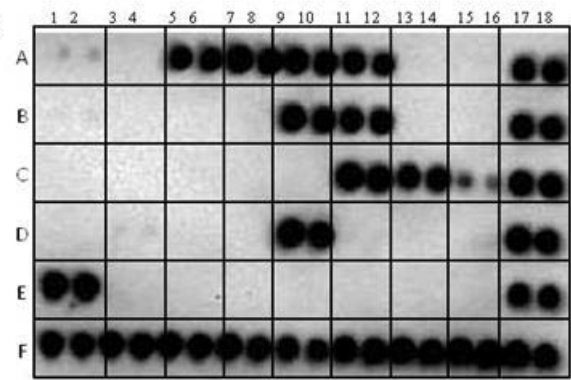

G

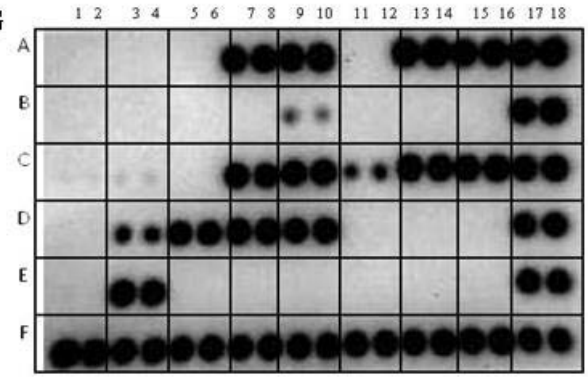

$\mathrm{B}$

MRP4 $C 10$ wt peptide: biotin-KSGSG-STLTIFETAL $\mathrm{COOH}_{\mathrm{H}}$ Linker MRP4

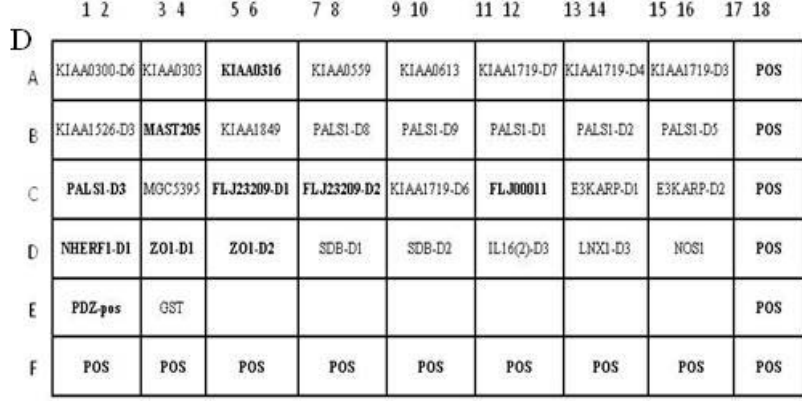

\begin{tabular}{|c|c|c|c|c|c|c|c|c|c|}
\hline & 12 & 34 & 56 & 78 & 910 & 1112 & 1314 & 516 & 1718 \\
\hline$A$ & MAGI3.D2 & MAO13-D4 & MAGI3-D5 & MAGI3.D6 & BAI.D2 & BAll-D3 & BAI1.D4 & BAI1-D1 & Pos \\
\hline B & BAN1-D6 & APPD2 & APP.D3 & APP.D4 & APP.DS & APP.D6 & hPTP1E.D2 & hPTPIE-D3 & Pos \\
\hline 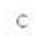 & WFTPIE.DA & PTPN4 & ORIP 1 -D4 & GRIP I-DS & GRIP $1-D$ & SCRIBI-DD & SCRIBI-D2 & SCRIBI-DS & POS \\
\hline D & PARD3.D2 & PARD3 D3 & HARM-D3 & MLLA & TIPI & SDB2.D2 & & & POS \\
\hline$E$ & PDZ,pos & GST & & & & & & & Pos \\
\hline & Pos & Pos & Pos & Pos & POS & POS & Pos & Pos & POS \\
\hline
\end{tabular}

\begin{tabular}{|c|c|c|c|c|c|c|c|c|c|}
\hline$H$ & 12 & 34 & 56 & 78 & 910 & 1112 & 1314 & 1516 & 1718 \\
\hline$A$ & MUPPI.D6 & MUPP1-D12 & MUPP1.D2 & MUPPIDS & MUPP1-D13 & MUPPIDI & DLG3.D2 & DLG3.D3 & pos \\
\hline B & DLos.D1 & DLOSSD4 & DLos.D3 & DLaS.D2 & DLG2.D3 & PAR68 & LIK1 & LOMP & POS \\
\hline 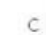 & RIL & A2L,M & TIAMI & LINYC & LIN7B & LINYA & GEFHI & GEF12 & Pos \\
\hline D & PDKZK1-DI & PDZK1.D2 & SNB1 & sval & sHK1 & MPP6 & PIST & GEF2 & pos \\
\hline E & RIM2 & PDZ,pos & GST & & & & & & Pos \\
\hline F & Pos & POS & POS & Pos & POS & Pos & pos & Pos & pos \\
\hline
\end{tabular}

Figure 3.1. Interaction of the MRP4 Class I PDZ domain with PDZ domains of various scaffolding proteins.

PDZ arrays (Panomics) II-IV (spotted with scaffolding proteins) probed with MRP4 peptide. (A) MRP4 biotinylated C-tail peptide (last 7 amino acids) (B) MRP4 biotinylated C-tail peptide (last 10 amino acids). (C,E,G) arrays II - IV probed with C7 MRP4 peptide; $(\mathrm{D}, \mathrm{F}, \mathrm{H})$ are a schematic representation of the scaffolding proteins on arrays II-IV. Scaffolding proteins in bold are the ones that specifically interacted with the MRP4 C7 peptide. 
Table 3.1. PDZ domains on arrays II, III and IV which bound with MRP4 C7 peptide.

\begin{tabular}{|c|c|c|c|c|}
\hline Position & PDZ Domain & Protein Name & $\begin{array}{l}\text { Interaction with MRP4 } \\
\text { Peptide }\end{array}$ & $\begin{array}{l}\text { Accession } \\
\text { No. }\end{array}$ \\
\hline \multicolumn{5}{|l|}{ Array II } \\
\hline $\mathrm{A} 1,2$ & KIAA0300-D6 & KIAA0300 protein, Domain 6 & & BAA20760 \\
\hline $\mathrm{A} 3,4$ & KIAA0303 & KIAA0303 protein & & BAA20762 \\
\hline A5, 6 & KIAA0316 & KIAA0316 protein & +++ & BAA20774 \\
\hline A7, 8 & KIAA0559 & KIAA0559 protein & & BAA25485 \\
\hline A9, 10 & KIAA0613 & KIAA0613 protein, Domain 7 & & BAA31588 \\
\hline A 11,12 & KIAA1719-D7 & KIAA1719 protein, Domain 7 & & BAB21810 \\
\hline $\mathrm{A} 13,14$ & KIAA1719-D4 & KIAA1719 protein, Domain 4 & & BAB21810 \\
\hline A 15,16 & KIAA1719-D3 & KIAA1719 protein, Domain 3 & & BAB21810 \\
\hline $\mathrm{B} 1,2$ & KIAA1526-D3 & KIAA 1526 protein, Domain 3 & & BAA96050 \\
\hline B3, 4 & MAST205 & $\begin{array}{l}\text { Microtubule-associated testis- } \\
\text { specific serine/threonine } \\
\text { protein kinase }\end{array}$ & +++ & BAB40778 \\
\hline B5, 6 & KIAA1849 & $\begin{array}{l}\text { Hypothetical protein } \\
\text { KIAA } 1849\end{array}$ & & BAB47478 \\
\hline B7, 8 & PALS1-D8 & $\begin{array}{l}\text { Pals1-associated tight junction } \\
\text { protein, Domain } 8\end{array}$ & & AAM28433 \\
\hline B9, 10 & PALS1-D9 & $\begin{array}{l}\text { Pals1-associated tight junction } \\
\text { protein, Domain } 9\end{array}$ & & AAM28433 \\
\hline $\mathrm{B} 11,12$ & PALS1-D1 & $\begin{array}{l}\text { Pals } 1 \text {-associated tight junction } \\
\text { protein, Domain } 1\end{array}$ & & AAM28433 \\
\hline $\mathrm{B} 13,14$ & PALS1-D2 & $\begin{array}{l}\text { Pals1-associated tight junction } \\
\text { protein, Domain } 2\end{array}$ & & AAM28433 \\
\hline $\mathrm{B} 15,16$ & PALS1-D5 & $\begin{array}{l}\text { Pals1-associated tight junction } \\
\text { protein, Domain } 5\end{array}$ & & AAM28433 \\
\hline
\end{tabular}


Table 3.1 (Continued).

\begin{tabular}{|c|c|c|c|c|}
\hline Position & PDZ Domain & Protein Name & $\begin{array}{l}\text { Interaction with } \\
\text { MRP4 Peptide }\end{array}$ & $\begin{array}{l}\text { Accession } \\
\text { No. }\end{array}$ \\
\hline $\mathrm{C} 1,2$ & PALS1-D3 & $\begin{array}{l}\text { Pals1-associated tight junction } \\
\text { protein, Domain } 3\end{array}$ & + & AAM28433 \\
\hline $\mathrm{C} 3,4$ & MGC5395 & $\begin{array}{l}\text { Similar to hypothetical protein } \\
\text { MGC5395 }\end{array}$ & & AAH12477 \\
\hline $\mathrm{C} 5,6$ & FLJ23209-D1 & $\begin{array}{l}\text { Hypothetical protein } \\
\text { FLJ23209, Domain } 1\end{array}$ & ++ & NP_079171 \\
\hline $\mathrm{C} 7,8$ & FLJ23209-D2 & $\begin{array}{l}\text { Hypothetical protein } \\
\text { FLJ23209, Domain } 2\end{array}$ & & NP_079171 \\
\hline $\mathrm{C} 9,10$ & KIAA1719-D6 & KIAA1719 protein, Domain 6 & & BAB21810 \\
\hline $\mathrm{C} 11,12$ & FLJ00011 & FLJ00011 protein (fragment) & + & Q9H7Q6 \\
\hline $\mathrm{C} 13,14$ & E3KARP-D1 & $\begin{array}{l}\text { Solute carrier family } 9 \text {, } \\
\text { sodium/hydrogen exchanger } 3 \\
\text { regulatory factor } 2 \text {, Domain } 1\end{array}$ & & NP_004776 \\
\hline $\mathrm{C} 15,16$ & E3KARP-D2 & $\begin{array}{l}\text { Solute carrier family } 9 \text {, } \\
\text { sodium/hydrogen exchanger } 3 \\
\text { regulatory factor } 2 \text {, Domain } 2\end{array}$ & & NP_004776 \\
\hline $\mathrm{D} 1,2$ & NHERF1-D1 & $\begin{array}{l}\text { Solute carrier family } 9 \text {, } \\
\text { sodium/hydrogen exchanger } \\
\text { Isoform } 3 \text { regulatory factor } 1 \text {, } \\
\text { Domain } 1\end{array}$ & +++ & NP_004243 \\
\hline D3, 4 & ZO1-D1 & $\begin{array}{l}\text { Tight junction protein } 1 \text {, } \\
\text { Domain } 1\end{array}$ & & Q07157 \\
\hline D5, 6 & ZO1-D2 & $\begin{array}{l}\text { Tight junction protein } 1 \text {, } \\
\text { Domain } 2\end{array}$ & & Q07157 \\
\hline
\end{tabular}


Table 3.1 (Continued).

\begin{tabular}{|c|c|c|c|c|}
\hline Position & PDZ Domain & Protein Name & $\begin{array}{l}\text { Interaction with MRP4 } \\
\text { Peptide }\end{array}$ & $\begin{array}{l}\text { Accession } \\
\text { No. }\end{array}$ \\
\hline D7, 8 & SDB1-D1 & $\begin{array}{l}\text { Syndecan binding protein } \\
\text { (syntenin), melanoma } \\
\text { differentiation associated } \\
\text { protein-9, Domain } 1\end{array}$ & & NP_005616 \\
\hline D9, 10 & SDB1-D2 & $\begin{array}{l}\text { Syndecan binding protein } \\
\text { (syntenin),melanoma } \\
\text { differentiation associated } \\
\text { protein-9, Domain } 2\end{array}$ & & NP_005616 \\
\hline D11, 12 & IL16(2)-D3 & $\begin{array}{l}\text { Interleukin } 16 \text { isoform } 2 \text {; } \\
\text { lymphocyte chemoattractant } \\
\text { factor, Domain } 3\end{array}$ & & NP_757366 \\
\hline D13, 14 & LNX1-D3 & $\begin{array}{l}\text { Numb-binding protein } 1 \text {; } \\
\text { Ligand of Numb-protein, } \\
\text { Domain } 3\end{array}$ & & Q8TBB1 \\
\hline D15,16 & NOS1 & $\begin{array}{l}\text { Nitric oxide synthase } 1 \\
\text { (neuronal), Domain } 5\end{array}$ & & NP_000611 \\
\hline $\mathrm{E} 1,2$ & PDZ-pos & $\begin{array}{l}\text { PDZ Domain positive control } \\
\text { forKv1.4 ligand }\end{array}$ & +++ & \\
\hline $\mathrm{E} 3,4$ & GST & Glutathione-S Transferase & & \\
\hline \multicolumn{5}{|l|}{ Array III } \\
\hline $\mathrm{A} 1,2$ & MAGI3-D2 & $\begin{array}{l}\text { Membrane-associated } \\
\text { guanylate kinase-related 3, } \\
\text { Domain } 2\end{array}$ & + & NP_690864 \\
\hline
\end{tabular}


Table 3.1 (Continued).

\begin{tabular}{|c|c|c|c|c|}
\hline Position & PDZ Domain & Protein Name & $\begin{array}{l}\text { Interaction with MRP4 } \\
\text { Peptide }\end{array}$ & $\begin{array}{l}\text { Accession } \\
\text { No. }\end{array}$ \\
\hline A3, 4 & MAGI3-D4 & $\begin{array}{l}\text { Membrane-associated } \\
\text { guanylate kinase-related 3, } \\
\text { Domain } 4\end{array}$ & & NP_690864 \\
\hline A5, 6 & MAGI3-D5 & $\begin{array}{l}\text { Membrane-associated } \\
\text { guanylate kinase-related 3, } \\
\text { Domain } 5\end{array}$ & +++ & NP_690864 \\
\hline A7, 8 & MAGI3-D6 & $\begin{array}{l}\text { Membrane-associated } \\
\text { guanylate kinase-related 3, } \\
\text { Domain } 6\end{array}$ & +++ & NP_690864 \\
\hline A9, 10 & BAI1-D2 & $\begin{array}{l}\text { Brain-specific angiogenesis } \\
\text { inhibitor-associated protein } 1 \text {, } \\
\text { Domain } 2\end{array}$ & +++ & NP_004733 \\
\hline A11, 12 & BAI1-D3 & $\begin{array}{l}\text { Brain-specific angiogenesis } \\
\text { inhibitor-associated protein } 1 \text {, } \\
\text { Domain } 3\end{array}$ & +++ & NP_004733 \\
\hline $\mathrm{A} 13,14$ & BAI1-D4 & $\begin{array}{l}\text { Brain-specific angiogenesis } \\
\text { inhibitor-associated protein } 1 \text {, } \\
\text { Domain } 4\end{array}$ & & NP_004733 \\
\hline A 15,16 & BAI1-D1 & $\begin{array}{l}\text { Brain-specific angiogenesis } \\
\text { inhibitor-associated protein } 1 \text {, } \\
\text { Domain } 1\end{array}$ & & NP_004733 \\
\hline $\mathrm{B} 1,2$ & BAI1-D6 & $\begin{array}{l}\text { Brain-specific angiogenesis } \\
\text { inhibitor-associated protein } 1 \text {, } \\
\text { Domain } 6\end{array}$ & & NP_004733 \\
\hline B3, 4 & AIP1-D2 & $\begin{array}{l}\text { Atrophin-1 interacting } \\
\text { protein } 1 \text {, Domain } 2\end{array}$ & & NP_036433 \\
\hline
\end{tabular}


Table $3.1 \quad$ (Continued).

\begin{tabular}{|c|c|c|c|c|}
\hline Position & PDZ Domain & Protein Name & $\begin{array}{l}\text { Interaction with MRP4 } \\
\text { Peptide }\end{array}$ & $\begin{array}{l}\text { Accession } \\
\text { No. }\end{array}$ \\
\hline $\mathrm{B} 5,6$ & AIP1-D3 & $\begin{array}{l}\text { Atrophin-1 interacting protein 1, } \\
\text { Domain3 }\end{array}$ & & NP_036433 \\
\hline B7, 8 & AIP1-D4 & $\begin{array}{l}\text { Atrophin-1 interacting protein 1, } \\
\text { Domain } 4\end{array}$ & & NP_036433 \\
\hline B9, 10 & AIP1-D5 & $\begin{array}{l}\text { Atrophin-1 interacting protein } 1 \text {, } \\
\text { Domain } 5\end{array}$ & +++ & NP_036433 \\
\hline B11, 12 & AIP1-D6 & $\begin{array}{l}\text { Atrophin-1 interacting protein } 1 \text {, } \\
\text { Domain } 6\end{array}$ & +++ & NP_036433 \\
\hline B13, 14 & hPTP1E-D2 & $\begin{array}{l}\text { Protein tyrosine phosphatase, } \\
\text { non-receptor type } 13 \text { isoform } 4 \text {, } \\
\text { Domain } 2\end{array}$ & & NP_542416 \\
\hline $\mathrm{B} 15,16$ & hPTP1E-D3 & $\begin{array}{l}\text { Protein tyrosine phosphatase, } \\
\text { non-receptor type } 13 \text { isoform } 4 \text {, } \\
\text { Domain } 3\end{array}$ & & NP_542416 \\
\hline $\mathrm{C} 1,2$ & hPTP1E-D4 & $\begin{array}{l}\text { Protein tyrosine phosphatase, } \\
\text { non-receptor type } 13 \text { isoform } 4 \text {, } \\
\text { Domain } 4\end{array}$ & & NP_542416 \\
\hline $\mathrm{C} 3,4$ & PTPN4 & $\begin{array}{l}\text { Protein tyrosine phosphatase, } \\
\text { non-receptor type } 4, \\
\text { megakaryocyte phosphatase; } \\
\text { PTPase-MEG1 }\end{array}$ & & NP_002821 \\
\hline $\mathrm{C} 5,6$ & GRIP1-D4 & GRIP1 protein, Domain 4 & & CAB39895 \\
\hline
\end{tabular}


Table 3.1 (Continued).

\begin{tabular}{|c|c|c|c|c|}
\hline Position & PDZ Domain & Protein Name & $\begin{array}{l}\text { Interaction with MRP4 } \\
\text { Peptide }\end{array}$ & $\begin{array}{l}\text { Accession } \\
\text { No. }\end{array}$ \\
\hline $\mathrm{C} 7,8$ & GRIP1-D3 & GRIP1 protein, Domain 3 & & CAB39895 \\
\hline $\mathrm{C} 9,10$ & GRIP1-D2 & GRIP1 protein, Domain 2 & & CAB39895 \\
\hline $\mathrm{C} 11,12$ & SCRIB1-D1 & Scribble, Domain 1 & +++ & NP_056171 \\
\hline $\mathrm{C} 13,14$ & SCRIB1-D2 & Scribble, Domain 2 & +++ & NP_056171 \\
\hline $\mathrm{C} 15,16$ & SCRIB1-D4 & Scribble, Domain 4 & ++ & NP_056171 \\
\hline D1, 2 & PARD3-D2 & $\begin{array}{l}\text { Partitioning-defective } \\
\text { protein } 3 \text { homolog; } \\
\text { atypical PKC isotype } \\
\text { isotypespecific } \\
\text { interacting protein, } \\
\text { Domain } 2\end{array}$ & & NP_062565 \\
\hline D3, 4 & PARD3-D3 & $\begin{array}{l}\text { Partitioning-defective } \\
\text { protein } 3 \text { homolog; } \\
\text { atypical PKC isotype } \\
\text { isotypespecificinteracting } \\
\text { protein, Domain } 2\end{array}$ & & NP_062565 \\
\hline D5, 6 & HARM-D3 & $\begin{array}{l}\text { Harmonin; PDZ-73 } \\
\text { protein; antigen NY-CO- } \\
\text { 38, Domain } 3\end{array}$ & & NP_005700 \\
\hline $\mathrm{D} 7,8$ & MLL4 & $\begin{array}{l}\text { Myeloid/lymphoid or } \\
\text { mixed-lineage leukemia, } \\
\text { translocated to } 4\end{array}$ & & NP_005927 \\
\hline D9, 10 & TIP1 & Tax interaction protein 1 & & NP_055419 \\
\hline
\end{tabular}


Table 3.1 (Continued).

\begin{tabular}{|c|c|c|c|c|}
\hline Position & PDZ Domain & Protein Name & $\begin{array}{l}\text { Interaction with MRP4 } \\
\text { Peptide }\end{array}$ & $\begin{array}{l}\text { Accession } \\
\text { No. }\end{array}$ \\
\hline $\mathrm{D} 11,12$ & SDB2-D2 & $\begin{array}{l}\text { Syntenin-2beta; syntenin-2; } \\
\text { similar to syndecan binding } \\
\text { protein, Domain } 2\end{array}$ & & NP_056500 \\
\hline $\mathrm{E} 1,2$ & PDZ-pos & $\begin{array}{l}\text { PDZ Domain positive control } \\
\text { forKv1.4 ligand }\end{array}$ & +++ & \\
\hline $\mathrm{E} 3,4$ & GST & Glutathione-S Transferase & & \\
\hline \multicolumn{5}{|l|}{ Array IV } \\
\hline $\mathrm{A} 1,2$ & MUPP1-D6 & $\begin{array}{l}\text { Multiple PDZ domain protein, } \\
\text { Domain } 6\end{array}$ & & NP_003820 \\
\hline $\mathrm{A} 3,4$ & MUPP1-12 & $\begin{array}{l}\text { Multiple PDZ domain protein, } \\
\text { Domain } 12\end{array}$ & & NP_003820 \\
\hline A5, 6 & MUPP1-2 & $\begin{array}{l}\text { Multiple PDZ domain protein, } \\
\text { Domain } 2\end{array}$ & & NP_003820 \\
\hline A7, 8 & MUPP1-3 & $\begin{array}{l}\text { Multiple PDZ domain protein, } \\
\text { Domain } 3\end{array}$ & +++ & NP_003820 \\
\hline A9, 10 & MUPP1-13 & $\begin{array}{l}\text { Multiple PDZ domain protein, } \\
\text { Domain } 13\end{array}$ & +++ & NP_003820 \\
\hline A11, 12 & MUPP1-1 & $\begin{array}{l}\text { Multiple PDZ domain protein, } \\
\text { Domain } 1\end{array}$ & & NP_003820 \\
\hline $\mathrm{A} 13,14$ & DLG3-D2 & $\begin{array}{l}\text { Synapse-associated protein } 102 \text {; } \\
\text { neuroendocrine-dlg; discs large } \\
\text { homolog } 3 \text {, Domain } 2\end{array}$ & +++ & NP_066943 \\
\hline
\end{tabular}


Table 3.1 (Continued).

\begin{tabular}{|c|c|c|c|c|}
\hline Position & PDZ Domain & Protein Name & $\begin{array}{l}\text { Interaction with MRP4 } \\
\text { Peptide }\end{array}$ & $\begin{array}{l}\text { Accession } \\
\text { No. }\end{array}$ \\
\hline $\mathrm{A} 15,16$ & DLG3-D3 & $\begin{array}{l}\text { Synapse-associated protein 102; } \\
\text { neuroendocrine-dlg; discs large } \\
\text { homolog 3, Domain3 }\end{array}$ & +++ & NP_066943 \\
\hline $\mathrm{B} 1,2$ & DLG5-D1 & Discs, large homolog 5, Domain 1 & & NP_004738 \\
\hline B3, 4 & DLG5-D4 & Discs, large homolog 5, Domain 4 & & NP_004738 \\
\hline B5, 6 & DLG5-D3 & Discs, large homolog 5, Domain 3 & & NP_004738 \\
\hline B7, 8 & DLG5-D2 & Discs, large homolog 5, Domain 2 & & NP_004738 \\
\hline B9, 10 & DLG2-D3 & $\begin{array}{l}\text { Channel associated protein of } \\
\text { synapse-110 (Chapsyn-110), } \\
\text { Domain } 3\end{array}$ & ++ & NP_001355 \\
\hline $\mathrm{B} 11,12$ & PAR6B & $\begin{array}{l}\text { Partitioning defective- } 6 \text { homolog } \\
\text { beta Domain } 1\end{array}$ & & BAB40756 \\
\hline $\mathrm{B} 13,14$ & LIK 1 & $\begin{array}{l}\text { LIM domain kinase } 1 \text { isoform } 1 \text {; } \\
\text { LIM motif-containing protein } \\
\text { kinase }\end{array}$ & & NP_002305 \\
\hline $\mathrm{B} 15,16$ & LOMP & $\begin{array}{l}\text { LIM domain only } 7 \text { isoform } \\
\text { a;KIAA } 0858 \text { protein }\end{array}$ & & NP_005349 \\
\hline $\mathrm{C} 1,2$ & RIL & $\begin{array}{l}\text { LIM protein RIL (Reversion- } \\
\text { induced LIM protein) }\end{array}$ & & NP_003678 \\
\hline $\mathrm{C} 3,4$ & A2LIM & $\begin{array}{l}\text { Alpha-actinin-2-associated LIM } \\
\text { protein;enigma homolog }\end{array}$ & + & NP_055291 \\
\hline
\end{tabular}


Table 3.1 (Continued).

\begin{tabular}{|c|c|c|c|c|}
\hline Position & PDZ Domain & Protein Name & $\begin{array}{l}\text { Interaction with MRP4 } \\
\text { Peptide }\end{array}$ & $\begin{array}{l}\text { Accession } \\
\text { No. }\end{array}$ \\
\hline $\mathrm{C} 5,6$ & TIAM1 & $\begin{array}{l}\text { T-cell lymphoma invasion and } \\
\text { metastasis } 1\end{array}$ & & NP_003244 \\
\hline $\mathrm{C} 7,8$ & LIN7C & Lin-7 homolog $C$ & +++ & NP_060832 \\
\hline $\mathrm{C} 9,10$ & LIN7B & Lin-7 homolog B & +++ & NP_071448 \\
\hline $\mathrm{C} 11,12$ & LIN7A & Lin-7 homolog A & +++ & NP_004655 \\
\hline $\mathrm{C} 13,14$ & GEF11 & $\begin{array}{l}\text { Rho guanine exchange factor } \\
\text { (GEF) } 11\end{array}$ & +++ & NP_055599 \\
\hline $\mathrm{C} 15,16$ & GEF12 & $\begin{array}{l}\text { Rho guanine exchange factor (GEF) } \\
12\end{array}$ & +++ & NP_056128 \\
\hline $\mathrm{D} 1,2$ & PDZK1-D1 & PDZ domain containing 1, Domain 1 & & NP_002605 \\
\hline D3, 4 & PDZK1-D2 & PDZ domain containing 1, Domain 2 & ++ & NP_002605 \\
\hline D5, 6 & SNB1 & $\begin{array}{l}\text { Beta-1-syntrophin; tax interaction } \\
\text { protein } 43\end{array}$ & +++ & NP_066301 \\
\hline $\mathrm{D} 7,8$ & SNA1 & $\begin{array}{l}\text { Acidic alpha } 1 \text { syntrophin; } \\
\text { dystrophin-associated protein A1 }\end{array}$ & +++ & NP_003089 \\
\hline D9, 10 & SHK1 & $\begin{array}{l}\text { Somatostatin receptor-interacting } \\
\text { protein; SH3 and multiple ankyrin } \\
\text { repeat domains } 1\end{array}$ & +++ & \\
\hline $\mathrm{D} 11,12$ & MPP6 & $\begin{array}{l}\text { Membrane protein, palmitoylated 6; } \\
\text { protein associated with Lin } 7 \text { 2;VELI- } \\
\text { associated MAGUK 1; MAGUK } \\
\text { protein p55T }\end{array}$ & & NP_057531 \\
\hline $\mathrm{D} 13,14$ & PIST & $\begin{array}{l}\text { Golgi associated and coiled-coil } \\
\text { motif containing protein }\end{array}$ & & NP_065132 \\
\hline
\end{tabular}


Table 3.1 (Continued).

\begin{tabular}{|c|c|c|c|c|}
\hline Position & PDZ Domain & Protein Name & $\begin{array}{l}\text { Interaction with MRP4 } \\
\text { Peptide }\end{array}$ & $\begin{array}{l}\text { Accession } \\
\text { No. }\end{array}$ \\
\hline $\mathrm{D} 15,16$ & GEF2 & $\begin{array}{l}\text { Rap guanine nucleotide exchange } \\
\text { factor; PDZ domain-containing } \\
\text { guanine nucleotide exchange } \\
\text { factor I }\end{array}$ & & NP_057424 \\
\hline $\mathrm{E} 1,2$ & RIM2 & $\begin{array}{l}\text { Regulating synaptic membrane } \\
\text { exocytosis 2; RAB3 interacting } \\
\text { protein 3; KIAA0751 protein 3; } \\
\text { KIAA0751 protein }\end{array}$ & & NP_055492 \\
\hline E3, 4 & PDZ-pos & $\begin{array}{l}\text { PDZ Domain positive control for } \\
\text { Kv1.4 ligand }\end{array}$ & +++ & \\
\hline E5, 6 & GST & Glutathione-S Transferase & & \\
\hline
\end{tabular}


Table 3.2. Potential PDZ proteins that interact with GPCRS which bound to MRP4 C7 peptide.

\begin{tabular}{|c|c|c|c|c|c|c|c|}
\hline $\begin{array}{l}\text { S. } \\
\text { No. }\end{array}$ & $\begin{array}{l}\text { Protein } \\
\text { Name }\end{array}$ & $\begin{array}{l}\text { Domains } \\
\text { on Array }\end{array}$ & $\begin{array}{l}\text { Domains } \\
\text { Interacting } \\
\text { with } \\
\text { MRP4 } \\
\text { peptide } \\
\end{array}$ & $\begin{array}{l}\text { Reported } \\
\text { Interaction with } \\
\text { Receptors }\end{array}$ & $\begin{array}{l}\text { Interacting } \\
\text { G Proteins }\end{array}$ & $\begin{array}{l}\text { Intensity } \\
\text { of Inter- } \\
\text { action }\end{array}$ & Ref \\
\hline 1 & NHERF1 & D1 & D1 & $\beta 1 \mathrm{AR}$ and $\beta 2 \mathrm{AR}$ & $\begin{array}{l}\text { Gas and } \\
\text { Gai }\end{array}$ & +++ & {$[70,72]$} \\
\hline 2 & MAGI3 & $\mathrm{D} 2,4,5,6$ & $\mathrm{D} 2,5,6$ & $\begin{array}{l}\beta 1 \mathrm{AR}, \beta 2 \mathrm{AR} \text { and } \\
\mathrm{LPA} 2\end{array}$ & 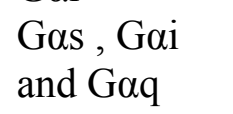 & $\begin{array}{l}+,+++ \\
+++\end{array}$ & {$[70,72,100]$} \\
\hline 3 & MUPP1 & $\mathrm{D} 1,2,3,6,12,13$ & D3, 13 & $\mathrm{Mt} 1,5-\mathrm{HT}_{2 \mathrm{C}} \mathrm{R}$ & $\begin{array}{l}\text { Gai and } \\
\text { Gaq }\end{array}$ &,++++++ & [80-82] \\
\hline 4 & GEF12 & & & LPA 1 and 2 & $\mathrm{G} \alpha 12 / 13$ & +++ & {$[\underline{85-87}]$} \\
\hline 5 & SNA1 & & & $\alpha_{1 D^{-}} \mathrm{AR}$ & $\mathrm{G} \alpha_{\mathrm{q}}$ & +++ & [83-84] \\
\hline
\end{tabular}


plasmids since this can create an artificial balance of proteins can drive artificial interactions. We tested instead for interactions between endogenously expressed proteins.

We were in search of a cell line where there is expression of MRP4 and $\beta 2 \mathrm{AR}$ (which belong to the family of GPCR and also have a class I PDZ domain interacting motif as MRP4). LNCaP cells met above criteria: These cells have higher expression of MRP4 [80, 81] and $\beta 2 \mathrm{AR}[62]$. MAGI3 appeared to be a potential scaffolding protein (out of the five proteins); we have observed interaction between MRP4 and MAGI 3 on array. A physical interaction has been reported earlier between $\beta 2 \mathrm{AR}$ and MAGI3 [82]. Even though there were no reports about MAGI3 expression in LNCaP cells, we hypothesized that MAGI3 may be expressed in these cells, and MRP4 and 32 ARare in complex may be through scaffolding protein MAGI3. The next aspect we wanted to explore was the expression of these three proteins in LNCaP cells.

\section{MRP4, $\beta 2 A R$ and MAGI3 are Co-Expressed in LNCaP Cells}

MRP4 and $\beta 2 A R$ are expressed in LNCaP cells $[62,80,81]$, and our results, which were obtained from RT-PCR and western blotting, showing mRNA and protein expression, respectively (Fig 3.2A, B), supported the published literature. We also observed mRNA expression of MUPP1 and protein expression of NHERF1 scaffolding proteins in LNCaP cells (data not shown). MAGI3 mRNA and protein expression was observed in LNCaP cells (Fig 3.2A, C). Expression of MRP4, $\beta 2 A R$ and MAGI3 mRNA was higher in LNCaP cells, compared to their expression in HT29-CL19A and Caco2 cell lines (data not shown). These expression results showed that all three proteins are expressed in this cell line. The next aspect we wanted to explore was whether there is any protein-protein interaction between these proteins.

\section{ABCC4/MRP4 Interacts with $\beta 2 A R$ in LNCaP Cells}

In our protein array experiment, MPR4 peptide (having the PDZ domain interacting motif) showed interaction with MAGI3 PDZ domains. It has already been shown that there is an interaction between MAGI3 and $\beta 2 A R$ [82]. We hypothesized that MRP4 may interact with $\beta 2 A R$ probably through MAGI3, a scaffolding protein in LNCaP cells. If all the three proteins are in macro molecular complex, then it would be possible to observe interaction between them by immunoprecipitation of one protein and co-immunoprecipitation of others. Immunoprecipitation of $\beta 2 \mathrm{AR}$ from $\mathrm{LNCaP}$ cells that were treated or untreated with isoproterenol is shown in Fig 3.3A. These results show pull down of $\beta 2$ AR using the 32 AR antibody. Immunoblotting of the $\beta 2$ AR pulled down eluate with anti-MRP4 and anti-MAGI3 antibodies, which showed that MRP4 was co-immunoprecipitated and that MAGI3 might also have been co-precipiated. Next, MRP4 was immunoprecipitated from LNCaP cells using MRP4 antibody (cells were treated or untreated with isoproterenol) (Fig 3.3B). Immunoblott analysis of the MRP4 pull down showed that 32 AR was co immunoprecipitated with MRP4 (Fig 3.3B). We were not able 

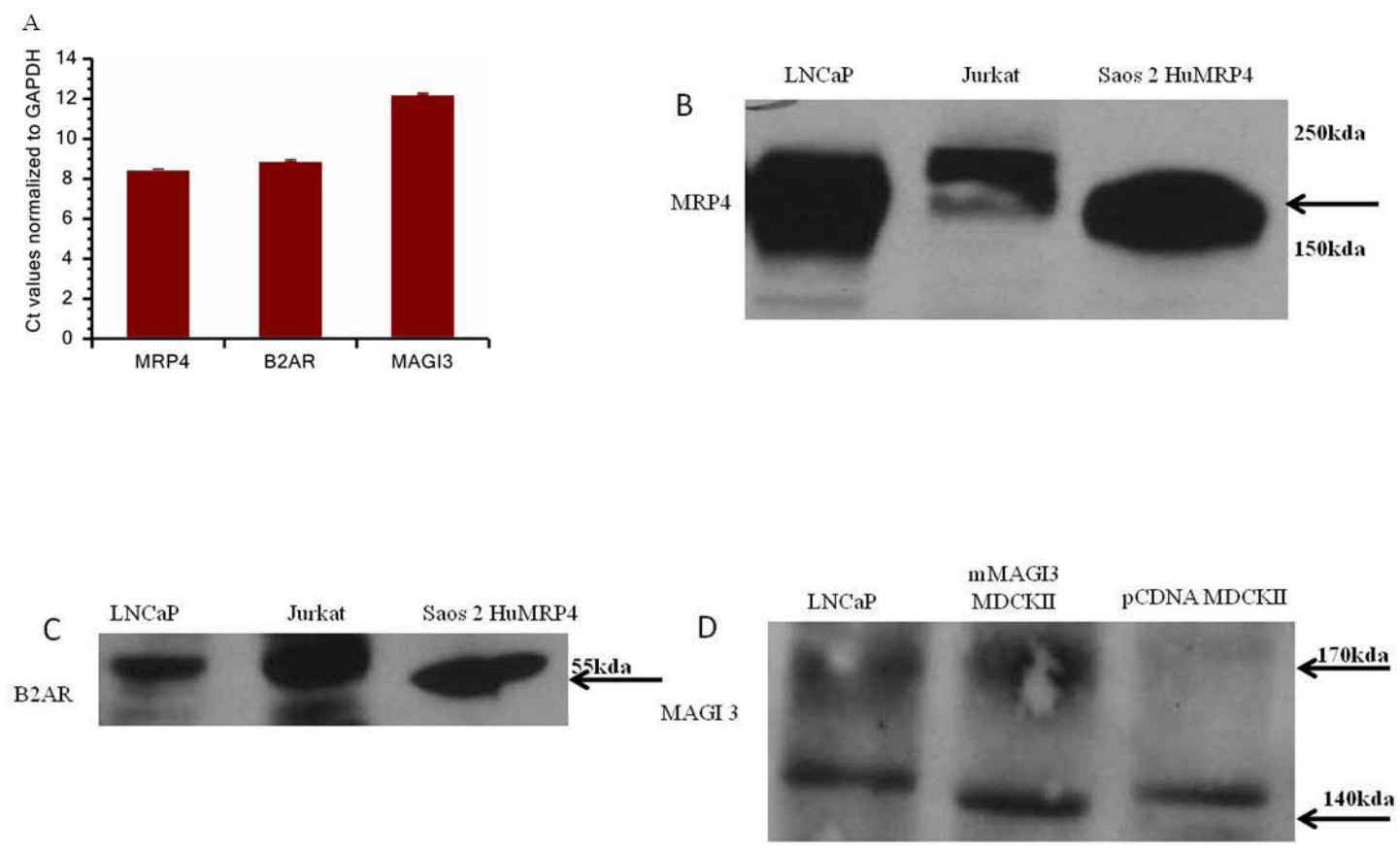

Figure 3.2. MRP4, B2AR and MAGI3 expression in LNCaP cells.

(A) RT-PCR results: MRP4, B2AR and MAGI3 mRNA expression (normalized by GAPDH expression) in LNCaP cells (average of two experiments \pm range). (B) Immunoblot analysis of MRP4 expression in LNCaP, Jurkat, and Saos2-MRP4 (over expressing MRP4) cells. (C) Immunoblot analysis of 32 AR expression in LNCaP, Jurkat, Saos2-MRP4 (over expressing MRP4) cells. (D) Immunoblot analysis of MAGI3 expression in LNCaP, MDCK II (over expressing MAGI3) and MDCK II (stably transfected with pCDNA) cells. 


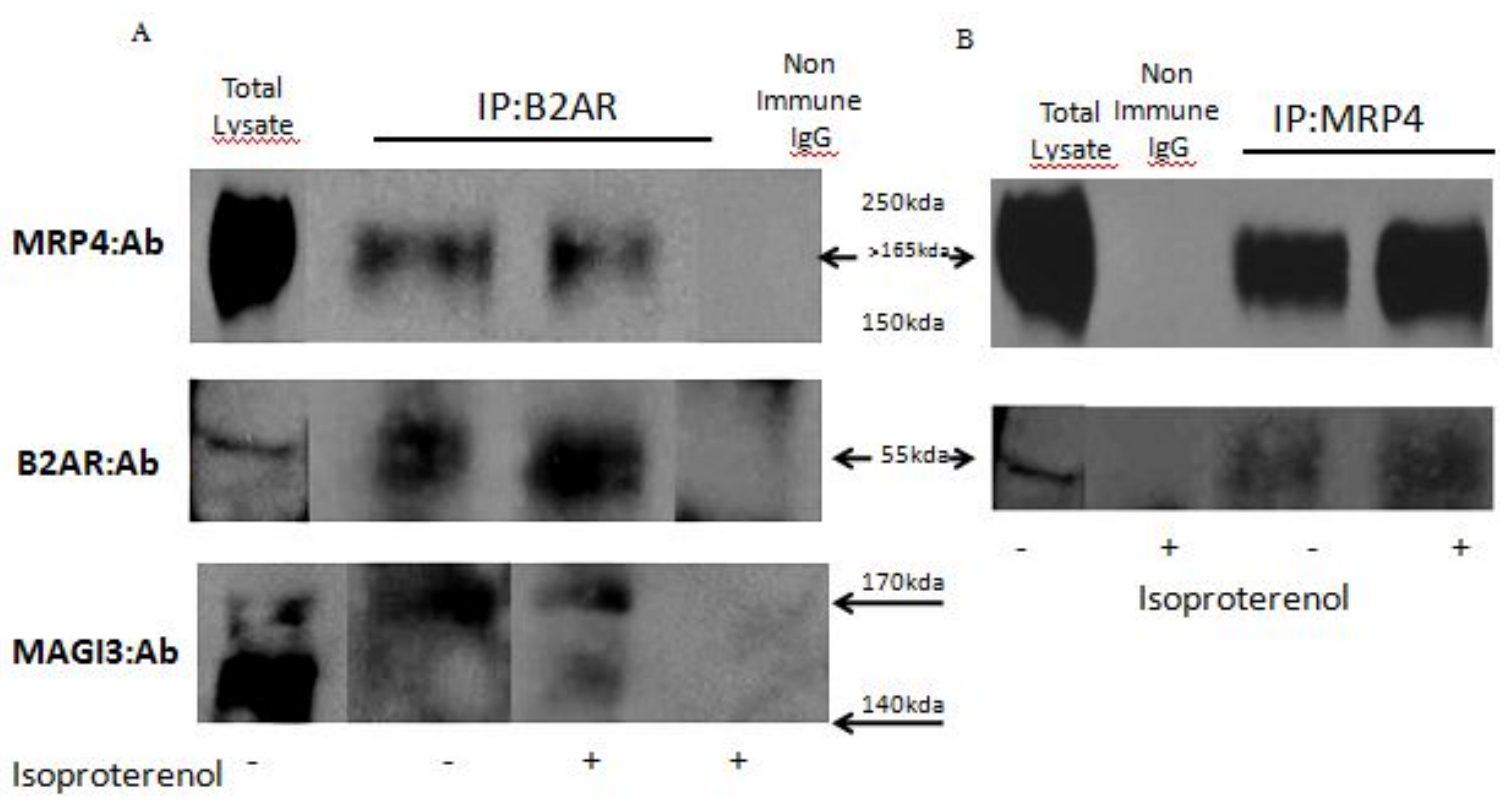

Figure 3.3. MRP4 interacts with B2AR through scaffolding protein MAGI3.

(A) LNCaP cells treated or untreated with Isoproterenol were lysed. These lysates were used for immunoprecipitation with anti $32 \mathrm{AR}$ antibody and then were immunoblotted for MRP4 and MAGI3. (B) LNCaP lysates were used for immunoprecipitation with anti MRP4 antibody and then were immunoblotted for $\beta 2 A R$ and MAGI3. 
to see clear co-immunoprecipitation of MAGI3 with pull down by the MRP4 antibody (not shown). We are not sure why this discrepancy is observed between the pull down of B2AR or MRP4 antibody. As mentioned above, we repeatedly found that MAGI3 was co-immunoprecipitated when immunoprecipitation was carried out by $\beta 2 \mathrm{AR}$. In total, the results of the immunoprecipitation showed there is definitely a physical association between MRP4 and $\beta 2 \mathrm{AR}$. This asscociation may be mediated by the scaffolding protein MAGI3.

\section{Inhibition of MRP4 along with $\beta 2 A R$ Activation Modifies cAMP Signaling}

Next we tested whether there is any functional association between MRP4 and the $\beta 2 \mathrm{AR}$. The $\beta 2 \mathrm{AR}$ belongs to the family of GPCRs, which interacts with different types of $\mathrm{G}$ proteins. It has been reported that in $\mathrm{LNCaP}$ cells, the $32 \mathrm{AR}$ interacts with Gs proteins. Activation of $\beta 2 \mathrm{AR}$ increases its interaction with Gs proteins, stimulating adenylyl cyclase and subsequently increasing cAMP levels [62]. MRP4 is a high affinity cAMP transporter, which is also expressed in LNCaP cells as shown in our above results and also reported previously $[80,81]$. We hypothesized that if LNCaP cells were activated with isoproterenol, a $\beta 2 \mathrm{AR}$ agonist, this would result in an increase in cAMP levels. We further hypothesized that if MRP4 efflux of cAMP modified $\beta 2 A R$-induced cAMP signaling, then inhibition of MRP4 with a specific inhibitor would further increase the isoproteronol-stimulated cAMP signal. We also tested whether simply inhibiting MRP4 in cells (in the absence of B2AR activation) would increase endogenous cAMP pools and result in increased cAMP signaling. Changes in cAMP levels were examined by using a CRE-luc reporter assay system, because cAMP effects transcription of downstream target genes through activation of the cAMP response element (CRE) [83, 84]

LNCaP cells were transiently transfected with control and CRE-luc reporter, respectively, and treated with vehicle, or the MRP4 specific inhibitor MK571 or the $\beta 2 \mathrm{AR}$ agonist isoproteronol, or a combination of the $32 \mathrm{AR}$ agonist and MRP4 inhibitor, respectively (Fig 3.4). When vehicle treatmentwas compared with the MRP4 inhibitor treatment, there was a small but not significant increase in cAMP signaling. Treatment with the $\beta 2 \mathrm{AR}$ agonist isoproteronol alone significantly increased cAMP signaling, and co-treatment with the MRP4 inhibitor further increased cAMP signaling. This combination also showed the highest increase in CRE-luc levels. These results confirm the functional association between MRP4 and B2AR. 


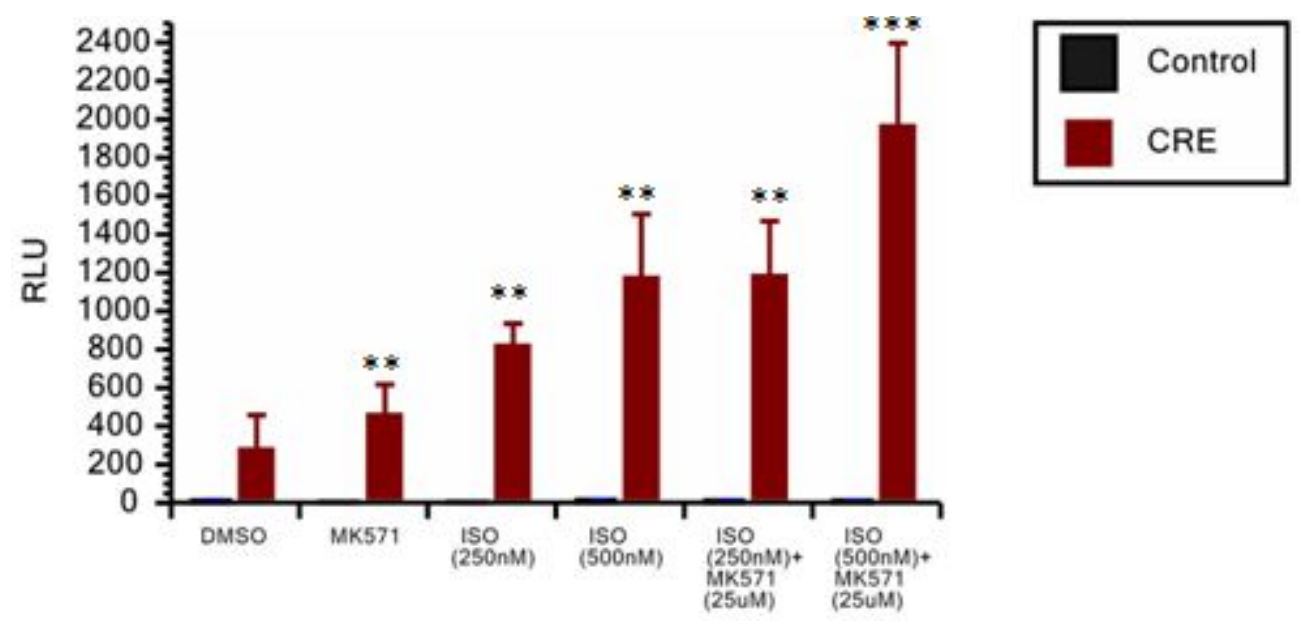

Figure 3.4. Activation of B2AR along with inhibition of MRP4 modifies CAMP signaling (CRE-Luc activity).

LNCaP cells were cotransfected with control-MetLuc2 reporter and pSEAP2 (secreted alkaline phosphate) control vector or CRE-MetLuc2 and SEAP2 control vector. Cells were incubated for $24 \mathrm{hrs}$ after treating with vehicle (0.1\% DMSO), MK571 $(25 \mu \mathrm{M})$, Isoproteronol (ISO $250 \mathrm{nM}$ ), ISO( $250 \mathrm{nM})+$ MK571, ISO (500nM), and ISO $(500 \mathrm{nM})+$ MK571, respectively. Each point represents the mean \pm S.E.M. of normalized luciferase activities performed in triplicates. $* * p<0.05$ compared with DMSO treated cells. ${ }^{* * *} \mathrm{p}<0.009$ compared with DMSO treated cells. RLU, relative luciferase units. 


\section{CHAPTER 4. DISCUSSION}

\section{Summary of Conclusions}

MRP4 plays an essential role in regulation of intracellular cAMP levels. This regulation parallels the role of phosphodiesterases, which also regulate cAMP levels through hydrolysis of cAMP. There have been a number of studies which showed that MRP4 regulates cAMP levels in different cell types, but only one study has shown that this regulation is possible due to physical and functional association of MRP4 with another ABC transporter, CFTR, through its PDZ interacting motif. CFTR is a major regulator of fluid homeostasis, and changes in CFTR function could lead to a disturbance of fluid homeostasis resulting in diseases like cystic fibrosis, secretary diarrhea or inflammatory bowel syndrome. MRP4 is an efflux transporter of cAMP, and CFTR is a Clchannel whose function depends on the cAMP levels. If cAMP levels are low, this condition may lead to inflammatory bowel syndrome, and when cAMP levels are high, this condition may lead to secretary diarrhea. MRP4 regulates localized cAMP levels and aids in maintaining fluid homeostasis, along with CFTR. This regulation and association is possible because both CFTR and MRP4 bind to a scaffolding protein, PDZK1, through their PDZ interacting motifs. PDZK1 plays a role in holding the macromolecular complex of CFTR and MRP4, leading to the functional association of MRP4 and CFTR [36]. In another study, it has been observed that interaction of MRP4 through its PDZ interacting motif with a scaffolding protein, NHERF1, may play a role in MRP4 apical localization in polarized cells [47].

In this study, we found that MRP4, through its PDZ interacting motif, interacts with several other scaffolding proteins, along with PDZK1 [15] and NHERF1 [47]. We also observed that there is a functional and physical association of MRP4 with $\beta 2 \mathrm{AR}$. This interaction is possible because both MRP4 and $\beta 2 A R$ bind to scaffolding proteins through their PDZ interacting motifs. From our results, it is possible that the scaffolding protein that holds this macromolecular complex is MAGI3. Further studies have to be carried out to confirm whether MAGI3 is the only scaffolding protein that holds this complex or there are any other proteins which may carry out the same function when MAGI3 is knocked down. We think that the scaffolding protein could be MAGI3 because MRP4, $\beta 2 \mathrm{AR}$ and MAGI3 are co-expressed in LNcAP cells, and co-immunoprecipitation studies showed a physical association between MRP4 and $\beta 2 \mathrm{AR}$ and a weak interaction with MAGI3. None of these interactions was changed by treatment with the $32 \mathrm{AR}$ agonist isoproteronol. Finally, we also observed a functional association between MRP4 and $\beta 2 A R$. We showed that inhibition of MRP4 could modify $32 A R$-induced cAMP signaling in LNCaP cells. Nevertheless, it remains possible that other scaffolding proteins, such as NHERF1 and PDZK1 (whose proteins we detected in LNCaP cells), could also serve as scaffolds for MRP4 and B2AR in these cells, and this possibility remains to be tested

It remains to be determined whether scaffolding proteins facilitate MRP4's

interaction with any other receptors or proteins or modulate MRP4 efflux of cAMP. In rat 
smooth muscle cells, it has been observed that MRP4 regulates intracellular cAMP levels. Inhibition of MRP4 leads to increase in intracellular cAMP, thus leading to an antiproliferative effect on rat smooth muscle cells. In these cells, MRP4 negatively regulates the cAMP dependent signal transduction pathways [85]. This anti proliferative effect by inhibition and knockdown of MRP4 has been observed in human leukemic cell lines as well. This effect is due to the increase in intracellular cAMP levels. In human leukemic cells, MRP4 controls intracellular cAMP levels, leading to increase in cell proliferation and preventing differentiation and maturation [86]. It also has been shown that MRP4 plays a role in retinal angiogenesis. When human retinal endothelial cells are treated with increasing concentration of VEGF, there is a decreased expression of MRP4. Knock down of MRP4 in hRECs has shown suppression of apoptosis, increase in migration of cells and formation cell aggregates-all of which may be due to the increase in intracellular cAMP levels [87]. Recently, it has been shown that MRP4 regulates cAMP levels in pulmonary arterial smooth muscle cells. In patients with pulmonary arterial hypertension, MRP4 expression has been observed to be increased. Inhibition of MRP4 leads to decrease in the proliferation and migration of pulmonary arterial endothelial cells of mice [88]. All these observations show that MRP4 is a major regulator of intracellular cAMP levels. It would be interesting to see whether this regulation involves the role of PDZ interacting motif. Exploring this question may lead to finding other interacting partners of MRP4 and scaffolding proteins that may be responsible for regulating cAMP along with MRP4.

MAGI3 is a scaffolding protein that binds to GPCRs like LPA2 receptor and negatively regulates LPA2 invasion and cell migration in colon cancer cell line. NHERF2 also interacts with LPA2 in the same cells and has an opposite effect on invasion and migration compared to that of MAGI3. This differential regulation is possible because MAGI3 couples LPA2 with $\mathrm{G} \alpha_{\mathrm{q}}$ and $\mathrm{G} \alpha_{12}$, while NHERF2 couples LPA2 only with $\mathrm{G} \alpha_{\mathrm{q}}$. Both MAGI3 and NHERF2 compete for binding to LPA2 receptor,. It has been observed that knock down of MAGI3 leads to increased association of NHERF2 to LPA2.LPA2 expression is higher in prostate cancer [89]. We hypothesized that MAGI3 may also present in prostate cancer cells and have shown evidence to support this hypothesis in our results. MAGI3 also binds to both $\beta_{1}$ and $\beta 2 \mathrm{AR}[31,77]$. LNCaP cells show higher expression of $\beta 2 \mathrm{AR}[2,90]$. Even MRP4 is highly expressed in prostate cancer $[1,11]$. There may be a possibility that knock down of MAGI3 in LNCaP cells may lead to association of other PDZ proteins with MRP4 and $\beta 2 \mathrm{AR}$.

From the previous studies and our results, we propose a model depicting functional and physical association between MRP4 and $\beta 2 \mathrm{AR}$, probably through a PDZ scaffolding protein, MAGI3 (Fig 4.1). When B2AR is activated by isoproterenol, it interacts with the $\mathrm{G}_{\mathrm{s}}$ group of $\mathrm{G}$ proteins, stimulating adenylyl cyclase and subsequently increasing cAMP levels, leading to activation of PKC. This probably regulates downstream cAMP target gene expression. As B2AR and MRP4 are in a macromolecular complex, probably through scaffolding protein MAGI3, these increased levels of cAMP due to $32 A R$ activation are regulated by efflux of cAMP through the efflux transporter MRP4. The MRP4/ß2 AR/PDZ protein complex may aid in maintaining homeostasis of cAMP levels in cells along with PDE activity. 


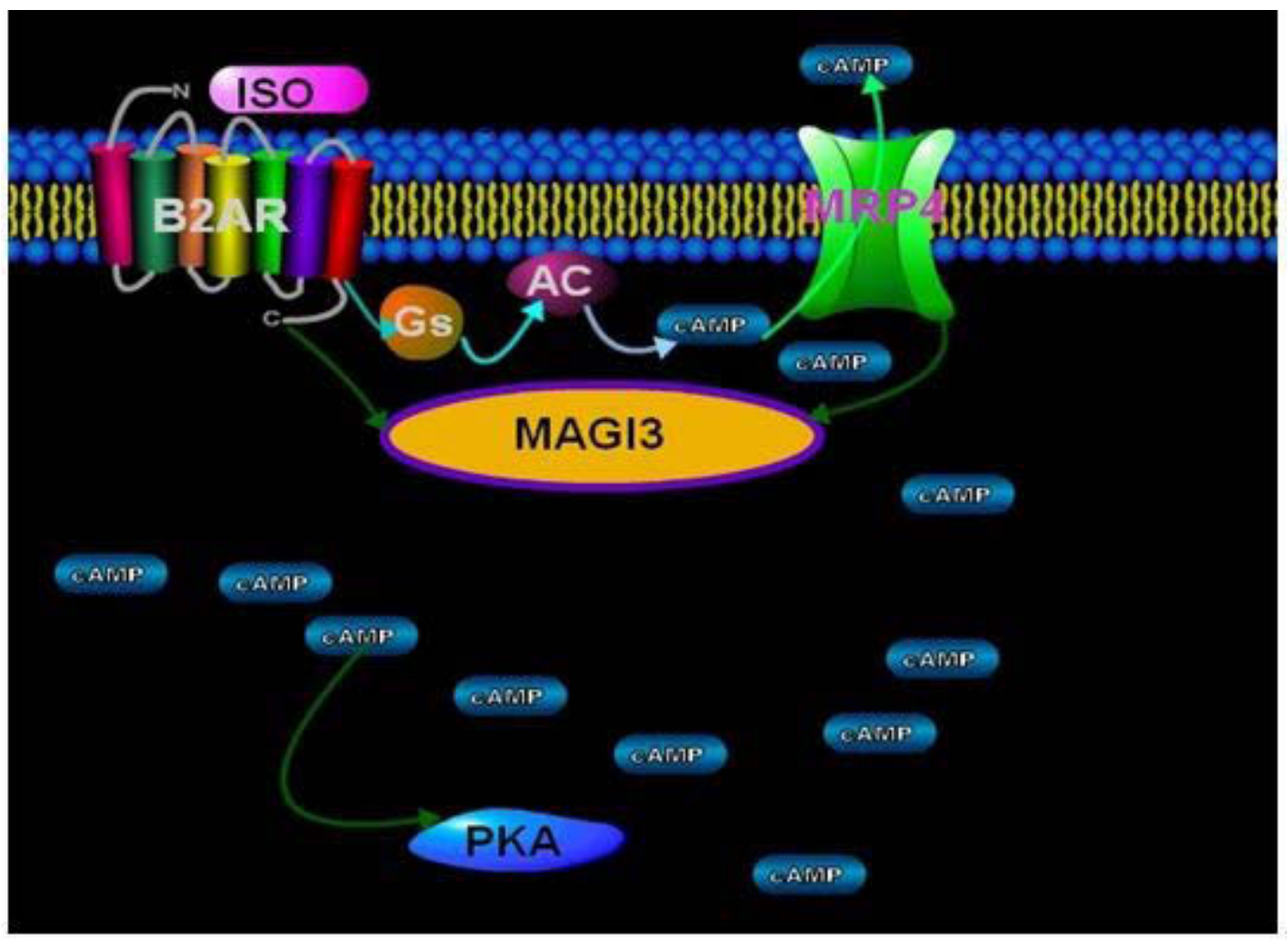

Figure 4.1. Schematic representation of physical and functional association of MRP4 with B2AR through a scaffolding protein, MAGI3, in prostate cancer cell line. 
In conclusion, MRP4 can bind to several scaffolding proteins through its PDZ interacting motif. Through this binding, MRP4 can interact with other transporters, receptors or ion channels, etc. and may have an effect on the transport of the substrates or downstream signaling pathways. In our study, we showed that MRP4 functionally and physically associates with $\beta 2 \mathrm{AR}$ in $\mathrm{LNCaP}$ cells. This association may regulate cAMP levels, subsequently regulating the downstream gene expression, which is dependent on cAMP signaling in LNCaP cells. This association of MRP4 and $\beta 2 \mathrm{AR}$ may be due to their binding to the scaffolding protein MAGI3.

\section{Future Studies}

We would like to see the effect on the macromolecular complex of MRP4, $\beta 2 \mathrm{AR}$ and MAGI3 when MAGI3 is knocked down using ShRNA MAGI3 Lentivirus particles. We hypothesize that there would be a break down in the physical and functional association of MRP4 and $\beta 2 \mathrm{AR}$. It would be also interesting to see if there were changes in intracellular and extracellular cAMP levels using cAMP assays, along with and without knock down of MAGI3. However, it also remains to be tested whether other PDZ proteins that interacted with MRP4 C7 peptide (PDZK1 and NHERF1) and that are expressed in LNCaP cells serve as a scaffold for MRP4 and $\beta 2 \mathrm{AR}$ and affect cAMP signaling. It would also be interesting to use confocal microscopy to see the localization of all three proteins:,MRP4, $\beta 2 \mathrm{AR}$ and MAGI3, in LNCaP cells. 


\section{LIST OF REFERENCES}

1. Cai, C., et al., Androgen induces expression of the multidrug resistance protein gene MRP4 in prostate cancer cells. Prostate Cancer Prostatic Dis, 2007. 10(1): p. 39-45.

2. Kasbohm, E.A., et al., Androgen receptor activation by $G(s)$ signaling in prostate cancer cells. J Biol Chem, 2005. 280(12): p. 11583-9.

3. Kool, M., et al., Expression of human MRP6, a homologue of the multidrug resistance protein gene MRP1, in tissues and cancer cells. Cancer Res, 1999. 59(1): p. 175-82.

4. $\quad$ Schuetz, J.D., et al., MRP4: A previously unidentified factor in resistance to nucleoside-based antiviral drugs. Nat Med, 1999. 5(9): p. 1048-51.

5. Russel, F.G., J.B. Koenderink, and R. Masereeuw, Multidrug resistance protein 4 (MRP4/ABCC4): a versatile efflux transporter for drugs and signalling molecules. Trends Pharmacol Sci, 2008. 29(4): p. 200-7.

6. Abla, N., et al., The human multidrug resistance protein 4 (MRP4, ABCC4): functional analysis of a highly polymorphic gene. J Pharmacol Exp Ther, 2008. 325(3): p. 859-68.

7. Lamba, J.K., et al., Nonsense mediated decay downregulates conserved alternatively spliced ABCC4 transcripts bearing nonsense codons. Hum Mol Genet, 2003. 12(2): p. 99-109.

8. Kato, Y., C. Watanabe, and A. Tsuji, Regulation of drug transporters by PDZ adaptor proteins and nuclear receptors. Eur J Pharm Sci, 2006. 27(5): p. 487500.

9. Milewski, M.I., et al., A PDZ-binding motif is essential but not sufficient to localize the C terminus of CFTR to the apical membrane. J Cell Sci, 2001. 114(Pt 4): p. 719-26.

10. Lee, K., et al., Isolation of MOAT-B, a widely expressed multidrug resistanceassociated protein/canalicular multispecific organic anion transporter-related transporter. Cancer Res, 1998. 58(13): p. 2741-7.

11. Ho, L.L., et al., Androgen regulation of multidrug resistance-associated protein 4 (MRP4/ABCC4) in prostate cancer. Prostate, 2008. 68(13): p. 1421-9.

12. Tomlins, S.A., et al., Integrative molecular concept modeling of prostate cancer progression. Nat Genet, 2007. 39(1): p. 41-51.

13. Mennone, A., et al., MRP4-/- mice have an impaired cytoprotective response in obstructive cholestasis. Hepatology, 2006. 43(5): p. 1013-21.

14. Leggas, M., et al., Mrp4 confers resistance to topotecan and protects the brain from chemotherapy. Mol Cell Biol, 2004. 24(17): p. 7612-21.

15. Li, C., et al., Spatiotemporal coupling of cAMP transporter to CFTR chloride channel function in the gut epithelia. Cell, 2007. 131(5): p. 940-51.

16. van Aubel, R.A., et al., The MRP4/ABCC4 gene encodes a novel apical organic anion transporter in human kidney proximal tubules: putative efflux pump for urinary cAMP and cGMP. J Am Soc Nephrol, 2002. 13(3): p. 595-603.

17. Chin, K.V., et al., Reinventing the wheel of cyclic AMP: novel mechanisms of cAMP signaling. Ann N Y Acad Sci, 2002. 968: p. 49-64. 
18. Wang, H.M., et al., Dual effects of 8-Br-cAMP on differentiation and apoptosis of human esophageal cancer cell line Eca-109. World J Gastroenterol, 2005. 11(41): p. 6538-42.

19. Marcelo, C.L., Differential effects of cAMP and cGMP on in vitro epidermal cell growth. Exp Cell Res, 1979. 120(1): p. 201-10.

20. Merkle, D. and R. Hoffmann, Roles of cAMP and cAMP-dependent protein kinase in the progression of prostate cancer: cross-talk with the androgen receptor. Cell Signal, 2011. 23(3): p. 507-15.

21. Jackson, E.K. and D.K. Raghvendra, The extracellular cyclic AMP-adenosine pathway in renal physiology. Annu Rev Physiol, 2004. 66: p. 571-99.

22. Milo, R., et al., BioNumbers--the database of key numbers in molecular and cell biology. Nucleic Acids Research, 2009. 38(Database): p. D750-D753.

23. Scott, J.D. and T. Pawson, Cell Signaling in Space and Time: Where Proteins Come Together and When They're Apart. Science, 2009. 326(5957): p. 12201224.

24. Tsunoda, S., et al., A multivalent PDZ-domain protein assembles signalling complexes in a G-protein-coupled cascade. Nature, 1997. 388(6639): p. 243-9.

25. Bhattacharyya, R.P., et al., Domains, motifs, and scaffolds: the role of modular interactions in the evolution and wiring of cell signaling circuits. Annu Rev Biochem, 2006. 75: p. 655-80.

26. Nourry, C., PDZ Domain Proteins: Plug and Play! Science's STKE, 2003. 2003(179): p. 7re-7.

27. Kato, Y., C. Watanabe, and A. Tsuji, Regulation of drug transporters by PDZ adaptor proteins and nuclear receptors. European Journal of Pharmaceutical Sciences, 2006. 27(5): p. 487-500.

28. Hung, A.Y., PDZ Domains: Structural Modules for Protein Complex Assembly. Journal of Biological Chemistry, 2001. 277(8): p. 5699-5702.

29. Thomas, M., et al., Oncogenic human papillomavirus E6 proteins target the MAGI-2 and MAGI-3 proteins for degradation. Oncogene, 2002. 21(33): p. 508896.

30. Zhang, H., et al., MAGI-3 regulates LPA-induced activation of Erk and RhoA. Cell Signal, 2007. 19(2): p. 261-8.

31. He, J., et al., Proteomic analysis of betal-adrenergic receptor interactions with PDZ scaffold proteins. J Biol Chem, 2006. 281(5): p. 2820-7.

32. Franklin, J.L., et al., Identification of MAGI-3 as a transforming growth factoralpha tail binding protein. Exp Cell Res, 2005. 303(2): p. 457-70.

33. Yao, R., Y. Natsume, and T. Noda, MAGI-3 is involved in the regulation of the JNK signaling pathway as a scaffold protein for frizzled and Ltap. Oncogene, 2004. 23(36): p. 6023-30.

34. Adamsky, K., et al., Junctional protein MAGI-3 interacts with receptor tyrosine phosphatase beta (RPTP beta) and tyrosine-phosphorylated proteins. J Cell Sci, 2003. 116(Pt 7): p. 1279-89.

35. Wu, Y., et al., Interaction of the tumor suppressor PTEN/MMAC with a PDZ domain of MAGI3, a novel membrane-associated guanylate kinase. J Biol Chem, 2000. 275(28): p. 21477-85. 
36. Li, C., et al., Spatiotemporal Coupling of cAMP Transporter to CFTR Chloride Channel Function in the Gut Epithelia. Cell, 2007. 131(5): p. 940-951.

37. Good, M.C., J.G. Zalatan, and W.A. Lim, Scaffold Proteins: Hubs for Controlling the Flow of Cellular Information. Science, 2011. 332(6030): p. 680-686.

38. Kato, Y., Xenobiotic transporter-adaptor network. Drug Metab Pharmacokinet, 2007. 22(6): p. 401-8.

39. Vaccaro, P. and L. Dente, PDZ domains: troubles in classification. FEBS Lett, 2002. 512(1-3): p. 345-9.

40. Torres, G.E., et al., Functional interaction between monoamine plasma membrane transporters and the synaptic PDZ domain-containing protein PICK1. Neuron, 2001. 30(1): p. 121-34.

41. Kato, Y., et al., PDZK1 directly regulates the function of organic cation/carnitine transporter OCTN2. Mol Pharmacol, 2005. 67(3): p. 734-43.

42. Anzai, N., et al., The multivalent PDZ domain-containing protein PDZK1 regulates transport activity of renal urate-anion exchanger URAT1 via its $C$ terminus. J Biol Chem, 2004. 279(44): p. 45942-50.

43. Kato, Y., et al., Screening of the interaction between xenobiotic transporters and PDZ proteins. Pharm Res, 2004. 21(10): p. 1886-94.

44. Sugiura, T., et al., Mutation in an adaptor protein PDZK1 affects transport activity of organic cation transporter OCTNs and oligopeptide transporter PEPT2. Drug Metab Pharmacokinet, 2006. 21(5): p. 375-83.

45. Sugiura, T., et al., PDZK1 regulates two intestinal solute carriers (Slc15a1 and Slc22a5) in mice. Drug Metab Dispos, 2008. 36(6): p. 1181-8.

46. Sugiura, T., Y. Kato, and A. Tsuji, Role of SLC xenobiotic transporters and their regulatory mechanisms $P D Z$ proteins in drug delivery and disposition. $\mathrm{J}$ Control Release, 2006. 116(2): p. 238-46.

47. Hoque, M.T., G. Conseil, and S.P. Cole, Involvement of NHERF1 in apical membrane localization of MRP4 in polarized kidney cells. Biochem Biophys Res Commun, 2009. 379(1): p. 60-4.

48. Watanabe, C., et al., $\mathrm{Na}+/ \mathrm{H}+$ exchanger 3 affects transport property of H+/oligopeptide transporter 1. Drug Metab Pharmacokinet, 2005. 20(6): p. 44351.

49. Noshiro, R., et al., The PDZ domain protein PDZK1 interacts with human peptide transporter PEPT2 and enhances its transport activity. Kidney Int, 2006. 70(2): p. 275-82.

50. Sugiura, T., et al., PDZ adaptors: Their regulation of epithelial transporters and involvement in human diseases. J Pharm Sci, 2011. 100(9): p. 3620-35.

51. Russel, F.G., R. Masereeuw, and R.A. van Aubel, Molecular aspects of renal anionic drug transport. Annu Rev Physiol, 2002. 64: p. 563-94.

52. Moyer, B.D., et al., A PDZ-interacting domain in CFTR is an apical membrane polarization signal. J Clin Invest, 1999. 104(10): p. 1353-61.

53. Miyazaki, H., et al., Modulation of renal apical organic anion transporter 4 function by two PDZ domain-containing proteins. J Am Soc Nephrol, 2005. 16(12): p. 3498-506. 
54. Watanabe, C., et al., PDZ adaptor protein PDZK2 stimulates transport activity of organic cation/carnitine transporter OCTN2 by modulating cell surface expression. Drug Metab Dispos, 2006. 34(11): p. 1927-34.

55. Short, D.B., et al., An apical PDZ protein anchors the cystic fibrosis transmembrane conductance regulator to the cytoskeleton. J Biol Chem, 1998. 273(31): p. 19797-801.

56. Zhang, Q., Z. Pan, and G. You, Regulation of human organic anion transporter 4 by protein kinase $C$ and NHERF-1: altering the endocytosis of the transporter. Pharm Res, 2010. 27(4): p. 589-96.

57. Swiatecka-Urban, A., et al., PDZ domain interaction controls the endocytic recycling of the cystic fibrosis transmembrane conductance regulator. J Biol Chem, 2002. 277(42): p. 40099-105.

58. Li, M., et al., NHERF-1 binds to Mrp2 and regulates hepatic Mrp2 expression and function. J Biol Chem, 2010. 285(25): p. 19299-307.

59. Hoque, M.T. and S.P. Cole, Down-regulation of $\mathrm{Na}+/ \mathrm{H}+$ exchanger regulatory factor 1 increases expression and function of multidrug resistance protein 4. Cancer Res, 2008. 68(12): p. 4802-9.

60. Cao, T.T., et al., A kinase-regulated PDZ-domain interaction controls endocytic sorting of the beta2-adrenergic receptor. Nature, 1999. 401(6750): p. 286-90.

61. Naren, A.P., et al., A macromolecular complex of beta 2 adrenergic receptor, CFTR, and ezrin/radixin/moesin-binding phosphoprotein 50 is regulated by PKA. Proc Natl Acad Sci U S A, 2003. 100(1): p. 342-6.

62. Kasbohm, E.A., Androgen Receptor Activation by Gs Signaling in Prostate Cancer Cells. Journal of Biological Chemistry, 2005. 280(12): p. 11583-11589.

63. Pierce, K.L., R.T. Premont, and R.J. Lefkowitz, Signalling: Seven-transmembrane receptors. Nature Reviews Molecular Cell Biology, 2002. 3(9): p. 639-650.

64. Brady, A.E. and L.E. Limbird, G protein-coupled receptor interacting proteins: emerging roles in localization and signal transduction. Cell Signal, 2002. 14(4): p. 297-309.

65. Hall, R.A., Beta-adrenergic receptors and their interacting proteins. Semin Cell Dev Biol, 2004. 15(3): p. 281-8.

66. He, J., et al., Interaction with cystic fibrosis transmembrane conductance regulator-associated ligand (CAL) inhibits betal-adrenergic receptor surface expression. J Biol Chem, 2004. 279(48): p. 50190-6.

67. Xu, J., et al., Beta 1-adrenergic receptor association with the synaptic scaffolding protein membrane-associated guanylate kinase inverted-2 (MAGI-2). Differential regulation of receptor internalization by MAGI-2 and PSD-95. J Biol Chem, 2001. 276(44): p. 41310-7.

68. Hu, L.A., et al., Beta 1-adrenergic receptor association with PSD-95. Inhibition of receptor internalization and facilitation of beta 1-adrenergic receptor interaction with $N$-methyl-D-aspartate receptors. J Biol Chem, 2000. 275(49): p. 38659-66.

69. Pak, Y., N. Pham, and D. Rotin, Direct binding of the betal adrenergic receptor to the cyclic AMP-dependent guanine nucleotide exchange factor CNrasGEF leads to Ras activation. Mol Cell Biol, 2002. 22(22): p. 7942-52. 
70. $\mathrm{Hu}, \mathrm{L} . \mathrm{A}$. , et al., GIPC interacts with the betal-adrenergic receptor and regulates betal-adrenergic receptor-mediated ERK activation. J Biol Chem, 2003. 278(28): p. 26295-301.

71. Xiao, R.P., Beta-adrenergic signaling in the heart: dual coupling of the beta2adrenergic receptor to $G(s)$ and $G(i)$ proteins. Sci STKE, 2001. 2001(104): p. re15.

72. Hall, R.A., et al., The beta2-adrenergic receptor interacts with the $\mathrm{Na}+/ \mathrm{H}+-$ exchanger regulatory factor to control $\mathrm{Na}+/ \mathrm{H}+$ exchange. Nature, 1998. 392(6676): p. 626-30.

73. Bello-Reuss, E., Effect of catecholamines on fluid reabsorption by the isolated proximal convoluted tubule. Am J Physiol, 1980. 238(5): p. F347-52.

74. Weinman, E.J., et al., Alpha and beta adrenergic agonists stimulate water absorption in the rat proximal tubule. J Membr Biol, 1982. 69(2): p. 107-11.

75. Maudsley, S., et al., Platelet-derived growth factor receptor association with $\mathrm{Na}(+) / \mathrm{H}(+)$ exchanger regulatory factor potentiates receptor activity. Mol Cell Biol, 2000. 20(22): p. 8352-63.

76. Hall, R.A., et al., A C-terminal motif found in the beta2-adrenergic receptor, $P 2 Y 1$ receptor and cystic fibrosis transmembrane conductance regulator determines binding to the $\mathrm{Na}+\mathrm{H}+$ exchanger regulatory factor family of $\mathrm{PDZ}$ proteins. Proc Natl Acad Sci U S A, 1998. 95(15): p. 8496-501.

77. Yang, X., et al., Beta-2 adrenergic receptor mediated ERK activation is regulated by interaction with MAGI-3. FEBS Lett, 2010. 584(11): p. 2207-12.

78. Hoque, M.T., G. Conseil, and S.P.C. Cole, Involvement of NHERF1 in apical membrane localization of MRP4 in polarized kidney cells. Biochemical and Biophysical Research Communications, 2009. 379(1): p. 60-4.

79. Kristiansen, K., Molecular mechanisms of ligand binding, signaling, and regulation within the superfamily of G-protein-coupled receptors: molecular modeling and mutagenesis approaches to receptor structure and function. Pharmacology \& Therapeutics, 2004. 103(1): p. 21-80.

80. Cai, C., et al., Androgen induces expression of the multidrug resistance protein gene MRP4 in prostate cancer cells. Prostate Cancer and Prostatic Diseases, 2006. 10(1): p. 39-45.

81. Ho, L.L., et al., Androgen regulation of multidrug resistance-associated protein 4 (MRP4/ABCC4) in prostate cancer. The Prostate, 2008. 68(13): p. 1421-1429.

82. Yang, X., et al., Beta-2 adrenergic receptor mediated ERK activation is regulated by interaction with MAGI-3. FEBS Letters, 2010. 584(11): p. 2207-2212.

83. Kim, J., The role of protein kinase A pathway and cAMP responsive elementbinding protein in androgen receptor-mediated transcription at the prostatespecific antigen locus. Journal of Molecular Endocrinology, 2005. 34(1): p. 107118.

84. Merkle, D. and R. Hoffmann, Roles of cAMP and cAMP-dependent protein kinase in the progression of prostate cancer: Cross-talk with the androgen receptor. Cellular Signalling, 2011. 23(3): p. 507-515.

85. Sassi, Y., et al., Multidrug resistance-associated protein 4 regulates $c$ AMPdependent signaling pathways and controls human and rat SMC proliferation. J Clin Invest, 2008. 118(8): p. 2747-57. 
86. Copsel, S., et al., Multidrug resistance protein 4 (MRP4/ABCC4) regulates cAMP cellular levels and controls human leukemia cell proliferation and differentiation. J Biol Chem, 2011. 286(9): p. 6979-88.

87. Tagami, M., et al., MRP4 knockdown enhances migration, suppresses apoptosis, and produces aggregated morphology in human retinal vascular endothelial cells. Biochem Biophys Res Commun, 2010. 400(4): p. 593-8.

88. Hara, Y., et al., Inhibition of MRP4 prevents and reverses pulmonary hypertension in mice. J Clin Invest, 2011. 121(7): p. 2888-97.

89. Lee, S.J., et al., MAGI-3 competes with NHERF-2 to negatively regulate LPA2 receptor signaling in colon cancer cells. Gastroenterology, 2011. 140(3): p. 92434.

90. Ramberg, H., et al., Hormonal regulation of beta2-adrenergic receptor level in prostate cancer. Prostate, 2008. 68(10): p. 1133-42. 


\section{VITA}

Praveen Kumar Potukuchi was born in Vijayawada, Andhra Pradesh, India, in 1979. He joined Utkal University in 1998 and received a Bachelor in Pharmacy degree in 2003. After completing his degree, Praveen worked as a Marketing Executive at Alembic Pharmaceuticals in India until 2004. In the same year he joined Orissa University of Agriculture and Technology for the Master's program in Bioinformatics and graduated in 2006. He served as a part-time lecturer at the Hi-Tech College of Pharmacy until 2007, and in fall 2008 he became a graduate student in the Integrated Program in Biomedical Sciences, The University of Tennessee Health Science Center, Memphis, TN. He will receive his Master of Science degree under the supervision of Dr. Erin Schuetz. 